March 2003 - NREL/TP-550-33108

\title{
Final Project Report for DPD, Inc. Office Building in Lansing, Michigan
}

M.Deru and M. Sherman

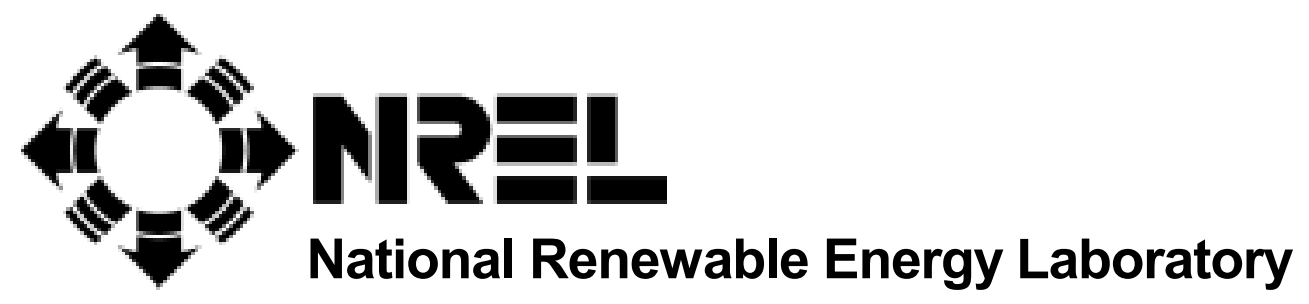

1617 Cole Boulevard

Golden, Colorado 80401-3393

NREL is a U.S. Department of Energy Laboratory

Operated by Midwest Research Institute $\bullet$ Battelle $\bullet$ Bechtel

Contract No. DE-AC36-99-G010337 


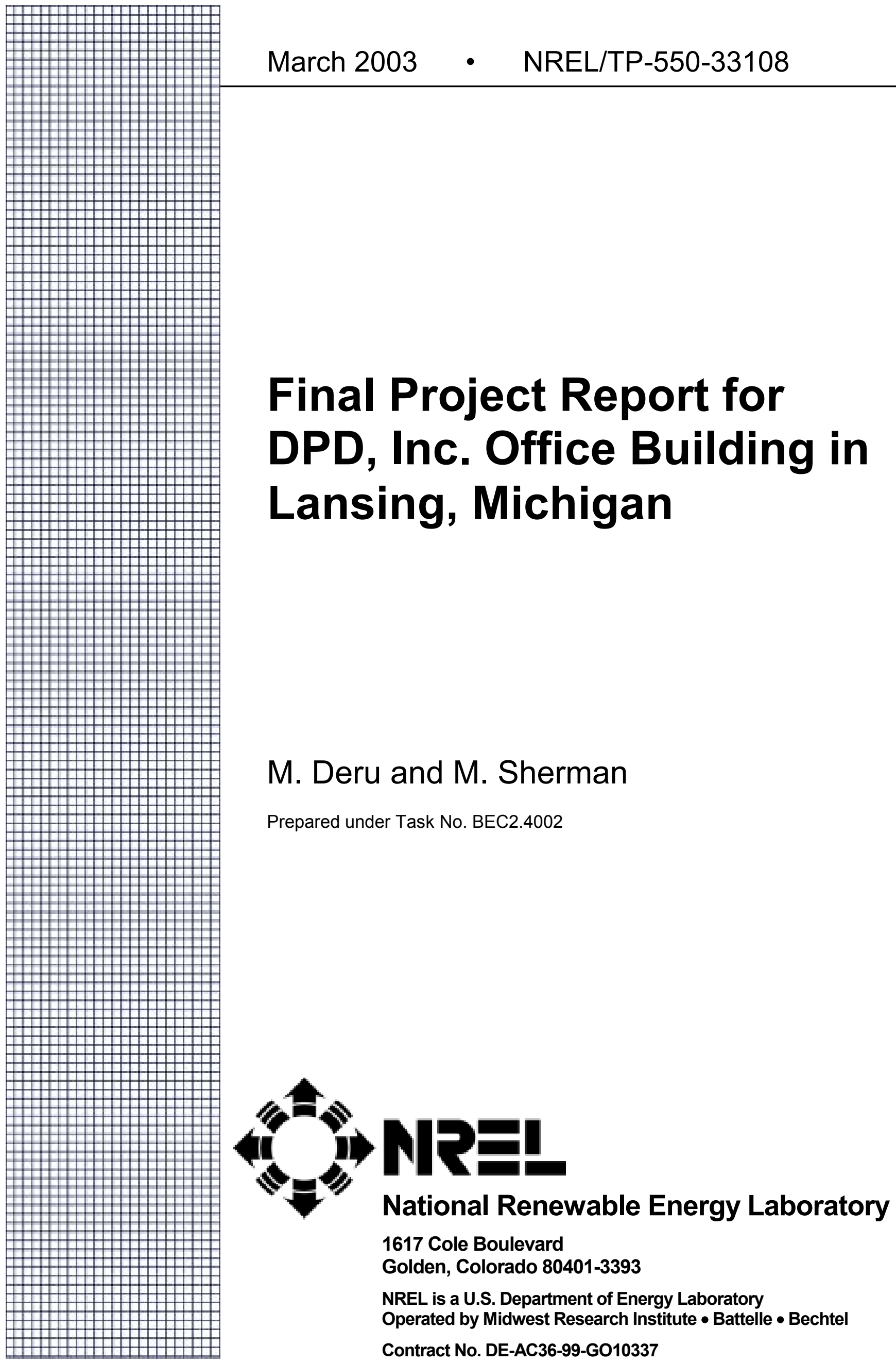




\section{NOTICE}

This report was prepared as an account of work sponsored by an agency of the United States government. Neither the United States government nor any agency thereof, nor any of their employees, makes any warranty, express or implied, or assumes any legal liability or responsibility for the accuracy, completeness, or usefulness of any information, apparatus, product, or process disclosed, or represents that its use would not infringe privately owned rights. Reference herein to any specific commercial product, process, or service by trade name, trademark, manufacturer, or otherwise does not necessarily constitute or imply its endorsement, recommendation, or favoring by the United States government or any agency thereof. The views and opinions of authors expressed herein do not necessarily state or reflect those of the United States government or any agency thereof.

Available electronically at http://www.osti.gov/bridge

Available for a processing fee to U.S. Department of Energy and its contractors, in paper, from:

U.S. Department of Energy

Office of Scientific and Technical Information

P.O. Box 62

Oak Ridge, TN 37831-0062

phone: 865.576 .8401

fax: 865.576.5728

email: reports@adonis.osti.gov

Available for sale to the public, in paper, from:

U.S. Department of Commerce

National Technical Information Service

5285 Port Royal Road

Springfield, VA 22161

phone: 800.553.6847

fax: 703.605.6900

email: orders@ntis.fedworld.gov

online ordering: http://www.ntis.gov/ordering.htm 


\section{Acknowledgments}

This work was made possible under the Department of Energy's (DOE's) Office of Energy Efficiency and Renewable Energy's High Performance Building's Initiative. We appreciate the support and guidance of Dru Crawley, DOE Program Manager for High Performance Buildings, as well as the following people who reviewed this document prior to publication: Paul Torcellini, Dennis Barley, and Ron Judkoff (National Renewable Energy Laboratory); Parviz Soroushian (Civil Engineering Professor, Michigan State University); and Farangis Jamzadeh (Vice President, DPD, Inc.). 


\section{Contents}

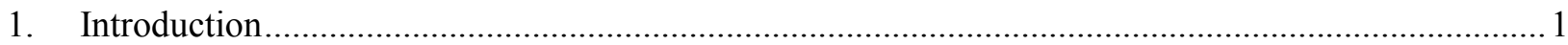

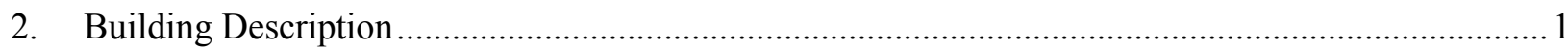

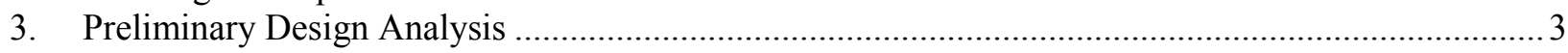

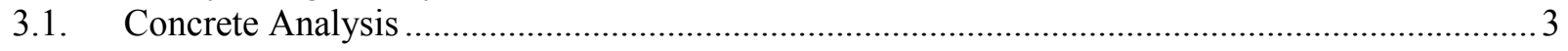

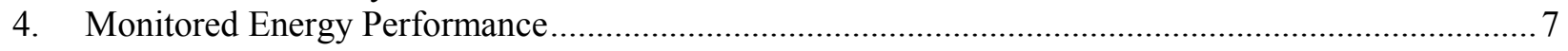

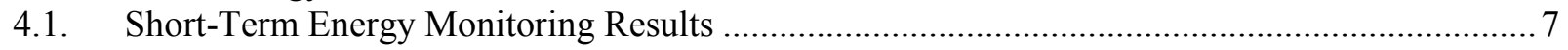

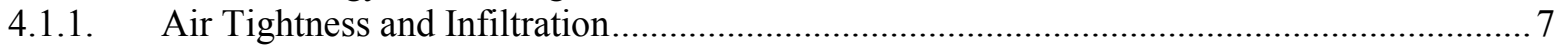

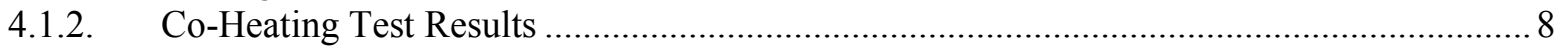

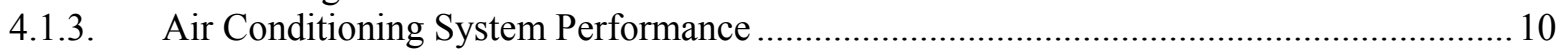

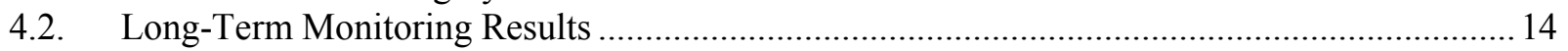

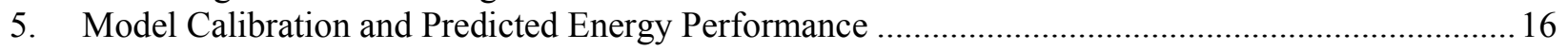

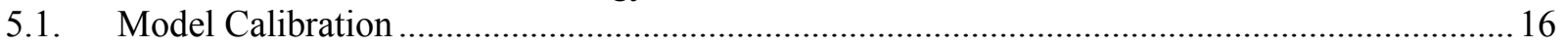

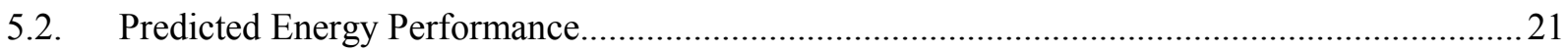

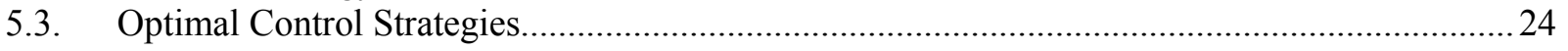

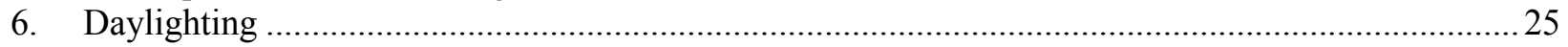

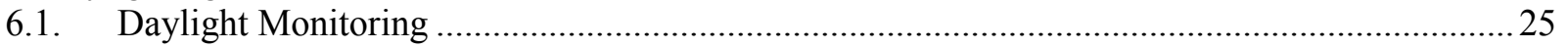

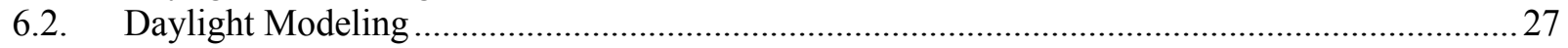

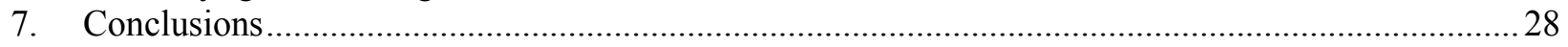

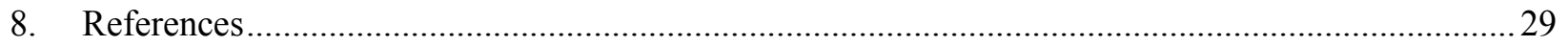




\section{Introduction}

The National Renewable Energy Laboratory (NREL) participated with DPD, Inc. in the thermal analysis of buildings constructed using concrete with recycled materials in the aggregate. This project was part of a Phase II Small Business Innovative Research (SBIR) grant to determine how the thermal properties of concrete can be "tuned" for use in passive solar buildings. DPD, Inc., and Michigan State University developed techniques to alter the thermal properties of concrete by introducing recycled materials into the aggregate. Two office/retail buildings were built in Lansing, Michigan, for this research. The objective of NREL's involvement was to evaluate the effects of concrete thermal properties on the building performance through energy simulations and monitoring.

This report presents a summary of the work accomplished on this project, including a predesign analysis of the concrete properties and building designs. After the buildings were constructed, the energy performance of each building was evaluated with short- and long-term monitoring techniques. These test results were used to calibrate computer models, and the models were used to predict long-term performance and compare control strategies in Lansing, Michigan, and Phoenix, Arizona.

\section{Building Description}

DPD, Inc. constructed two nearly identical small office/retail buildings in Lansing, Michigan, to study the use of high-recycled-content concrete. The buildings have a main floor and a basement with approximately $1270 \mathrm{ft}^{2}\left(118 \mathrm{~m}^{2}\right)$ per floor. The east half of the basement is completely underground; the west half is partially underground with the top $6 \mathrm{ft}(1.8 \mathrm{~m})$ of the walls above grade. Figure 1 shows the south building from the southeast direction on a clear December morning. The north building is constructed using standard concrete, and the south building uses concrete containing a large amount of mixed recycled plastics, which increases the volumetric and specific thermal capacities and decreases the thermal conductivity of the concrete. The thermal properties of various concrete materials are examined in Section 3.1.

The buildings have extremely high thermal mass with large south- and east-facing windows. A comparison of the construction details is presented in Table 1. The building shells are poured concrete construction with 8-in $(20.3 \mathrm{~cm})$ exterior walls, 12 -in $(30.5 \mathrm{~cm})$ flat roofs, and 6-in $(15.25 \mathrm{~cm})$ basement slab floors. All the insulation listed in Table 1 is installed on the exterior of the building. The windowslocated on the south, southeast, and east walls - have aluminum frames with a thermal break and clear double-pane low-e glazing units. The roof extends $5 \mathrm{ft}(1.5 \mathrm{~m})$ from the building to provide an overhang. The two buildings are close together, so the south building partially shades the north building at low sun angles. The average overall heat loss coefficient (UA value) of the south building is approximately 613 $\mathrm{Btu} / \mathrm{h} \cdot{ }^{\circ} \mathrm{F}(323 \mathrm{~W} / \mathrm{K})$, and the coefficient of the north building is approximately $694 \mathrm{Btu} / \mathrm{h} \cdot{ }^{\circ} \mathrm{F}(366 \mathrm{~W} / \mathrm{K})$. The difference is mainly due to the larger glass area and, to a lesser extent, the higher thermal conductivity of the concrete in the north building. 


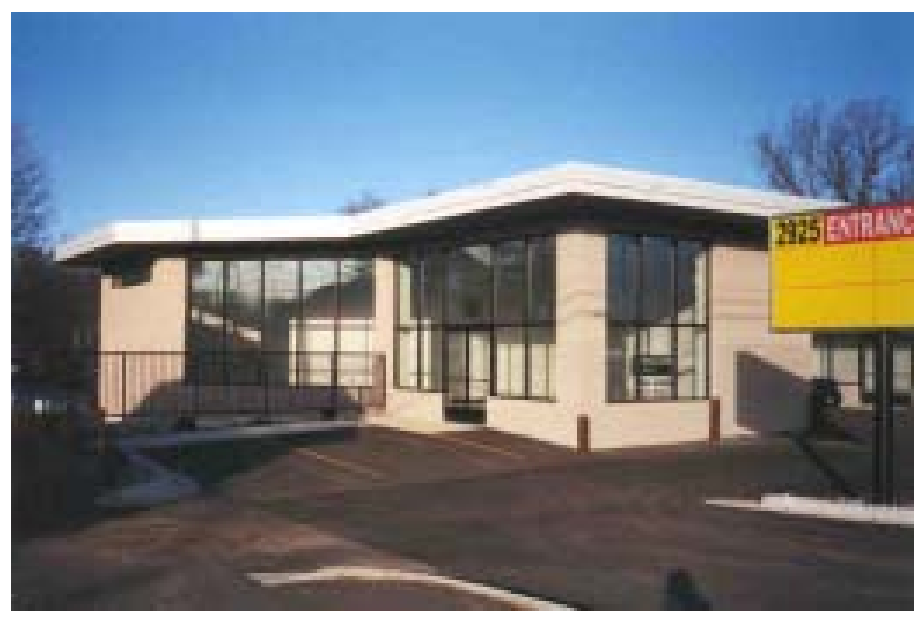

Figure 1. View of the south building from the southeast

Table 1. Comparison of the South and North Buildings

\begin{tabular}{|l|c|c|}
\hline \multicolumn{1}{|c|}{ Building Component } & South Building & North Building \\
\hline \hline Concrete type & Plastic aggregate & Standard \\
\hline $\begin{array}{l}\text { Above-grade wall insulation R-value } \\
\mathrm{h} \cdot \mathrm{ft}^{2} \cdot{ }^{\circ} \mathrm{F} / \mathrm{Btu}\left(\mathrm{m}^{2} \cdot \mathrm{K} / \mathrm{W}\right)\end{array}$ & $25.0(4.4)$ & $25.0(4.4)$ \\
\hline $\begin{array}{l}\text { Below-grade wall insulation R-value } \\
\mathrm{h} \cdot \mathrm{ft}^{2} \cdot{ }^{\circ} \mathrm{F} / \mathrm{Btu}\left(\mathrm{m}^{2} \cdot \mathrm{K} / \mathrm{W}\right)\end{array}$ & $15.0(2.6)$ & $15.0(2.6)$ \\
\hline Roof R-value $\mathrm{h} \cdot \mathrm{ft}^{2} \cdot{ }^{\circ} \mathrm{F} / \mathrm{Btu}\left(\mathrm{m}^{2} \cdot \mathrm{K} / \mathrm{W}\right)$ & $35.0(6.2)$ & $35.0(6.2)$ \\
\hline $\begin{array}{l}\text { Basement floor insulation R-value } \\
\mathrm{h} \cdot \mathrm{ft}^{2} \cdot{ }^{\circ} \mathrm{F} / \mathrm{Btu}\left(\mathrm{m}^{2} \cdot \mathrm{K} / \mathrm{W}\right)\end{array}$ & $10.0(1.8)$ & $10.0(1.8)$ \\
\hline Window area $\mathrm{ft}{ }^{2}\left(\mathrm{~m}^{2}\right)$ & $670(62.3)$ & $805(74.8)$ \\
\hline Building UA-value Btu $/ \mathrm{h} \cdot{ }^{\circ} \mathrm{F}\left(\mathrm{W} /{ }^{\circ} \mathrm{C}\right)$ & $613(323)$ & $694(366)$ \\
\hline
\end{tabular}

The large amount of window area provides significant daylighting. The main floor of the south building has lighting controls that dim continuously to about $28 \%$ of maximum power based on the amount of natural light in the space. There are currently no daylighting controls in the north building. Energy savings associated with daylighting in the north building will depend on educating the occupants to turn off the lights when there is enough natural light.

The south building has two 12-SEER (seasonal energy-efficiency ratio) air conditioning units: 4 tons for the main floor and 2 tons for the basement. The main-floor unit includes an economizer. The two-stage furnaces have an efficiency of $94 \%$ annual fuel utilization efficiency (AFUE) and have high/low ratings of $80 / 52 \mathrm{kBtu} / \mathrm{h}(23 / 15 \mathrm{~kW})$ for the main floor and $60 / 39 \mathrm{kBtu} / \mathrm{h}(18 / 11 \mathrm{~kW})$ for the basement. The furnace, fan, and evaporators are in the basement mechanical room; the condenser units are on the roof. The mechanical equipment for the north building is assumed to be the same, except there is no economizer. 


\section{Preliminary Design Analysis}

A preliminary design analysis was conducted on both buildings to optimize the energy designs and study the effects of the concrete thermal properties on energy requirements. Building-energy simulations were performed using two building energy analysis programs: DOE2.1E-107 [1], developed by the U.S. Department of Energy (DOE); and SUNREL version 1.0 [2], developed by NREL. DOE2.1E is an hourly simulation tool designed primarily for commercial buildings dominated by internal loads. SUNREL is also an hourly simulation program, but it was developed for small envelope-dominated buildings with high mass and high solar gain. Because the DPD buildings are small with high mass and high solar gains, SUNREL was used for the thermal analysis, and DOE2.1E was used for the daylighting analysis.

An analysis of the building design showed that the original design had excessive glazing on the south wall. The window area on the south wall of the south building was reduced by $135 \mathrm{ft}^{2}\left(12.5 \mathrm{~m}^{2}\right)$. Other changes made to the building designs during the analysis were added to both buildings.

\subsection{Concrete Analysis}

This section examines how the thermal properties of concrete affect the building energy loads. Table 2 lists the thermal properties of the concrete types studied in this project [3]. All of the concretes were modeled using one-dimensional heat transfer and assuming homogeneous properties. The aggregates comprise approximately $75 \%$ of the concrete by volume.

Table 2. Concrete Properties Used in This Study

\begin{tabular}{|c|c|c|c|c|}
\hline Case Name & $\begin{array}{l}\text { Specific Heat } \\
\left(\text { Btu/lb }{ }^{\circ} \mathbf{F}\right)\end{array}$ & $\begin{array}{c}\text { Density } \\
\left(\mathbf{l b} / \mathbf{f t}^{3}\right)\end{array}$ & $\begin{array}{c}\text { Thermal } \\
\text { Conductivity } \\
\left(\text { Btu } / \mathbf{h} \cdot \mathbf{f t} \cdot{ }^{\circ} \mathbf{F}\right) \\
\end{array}$ & $\begin{array}{c}\text { Thermal } \\
\text { Diffusivity } \\
\left(\mathrm{ft}^{2} / \mathbf{h}\right) \\
\end{array}$ \\
\hline $\mathrm{SSH}^{1}$ & 0.159 & 151.6 & 0.605 & 0.0251 \\
\hline SSH-HDPE $^{2}$ & 0.370 & 108.0 & 0.116 & 0.0029 \\
\hline SSH-PP ${ }^{3}$ & 0.335 & 112.9 & 0.122 & 0.0032 \\
\hline $\mathrm{SSH}_{-P V C}{ }^{4}$ & 0.398 & 108.0 & 0.103 & 0.0024 \\
\hline SSH-Rec. Conc. ${ }^{5}$ & 0.223 & 147.3 & 0.644 & 0.0196 \\
\hline SSH-Steel & 0.167 & 217.8 & 0.728 & 0.0200 \\
\hline SSH-Tire & 0.344 & 106.1 & 0.226 & 0.0062 \\
\hline SSH-Wood & 0.374 & 116.7 & 0.065 & 0.0015 \\
\hline SSH-Plastic ${ }^{6}$ & 0.32 & 125.0 & 0.16 & 0.0040 \\
\hline
\end{tabular}

${ }^{1} \mathrm{SSH}$ is standard concrete

${ }^{2}$ HDPE is high-density polyethylene

${ }^{3} \mathrm{PP}$ is polypropylene

${ }^{4} \mathrm{PVC}$ is polyvinyl chloride

${ }^{5} \mathrm{SSH}-\mathrm{Rec}$. Conc. uses recycled concrete for the aggregate

${ }^{6} \mathrm{SSH}-\mathrm{Plastic}$ combines HDPE, PP, and PVC in the aggregate

Figure 2 illustrates how the various concrete types affect the annual heating energy for a building similar to the DPD office buildings in Lansing, Michigan. The cooling load on each building was very similar and is therefore not shown. The graph shows that recycled-content concretes exhibit better thermal characteristics than the standard SSH concrete. The most effective recycled-content concrete is SSHWood, which exhibits a 17\% saving over the standard SSH concrete; the next best is the SSH-Plastic concrete, which reduces the annual heat load by almost $9 \%$. The savings are even greater for buildings with lower insulation levels (see Figure 5 and Section 5.2). The recycled-content concretes have a positive impact on building energy because of their high specific heat and low thermal conductivity. The thermal diffusivity is the ratio of the rate of heat conduction to the rate of heat storage in the material. It is 
interesting to note that the order of the heating energy used follows the order of the thermal diffusivity of the type of concrete used in the building. Figures 3 and 4 examine how specific heat and thermal conductivity affect building energy.

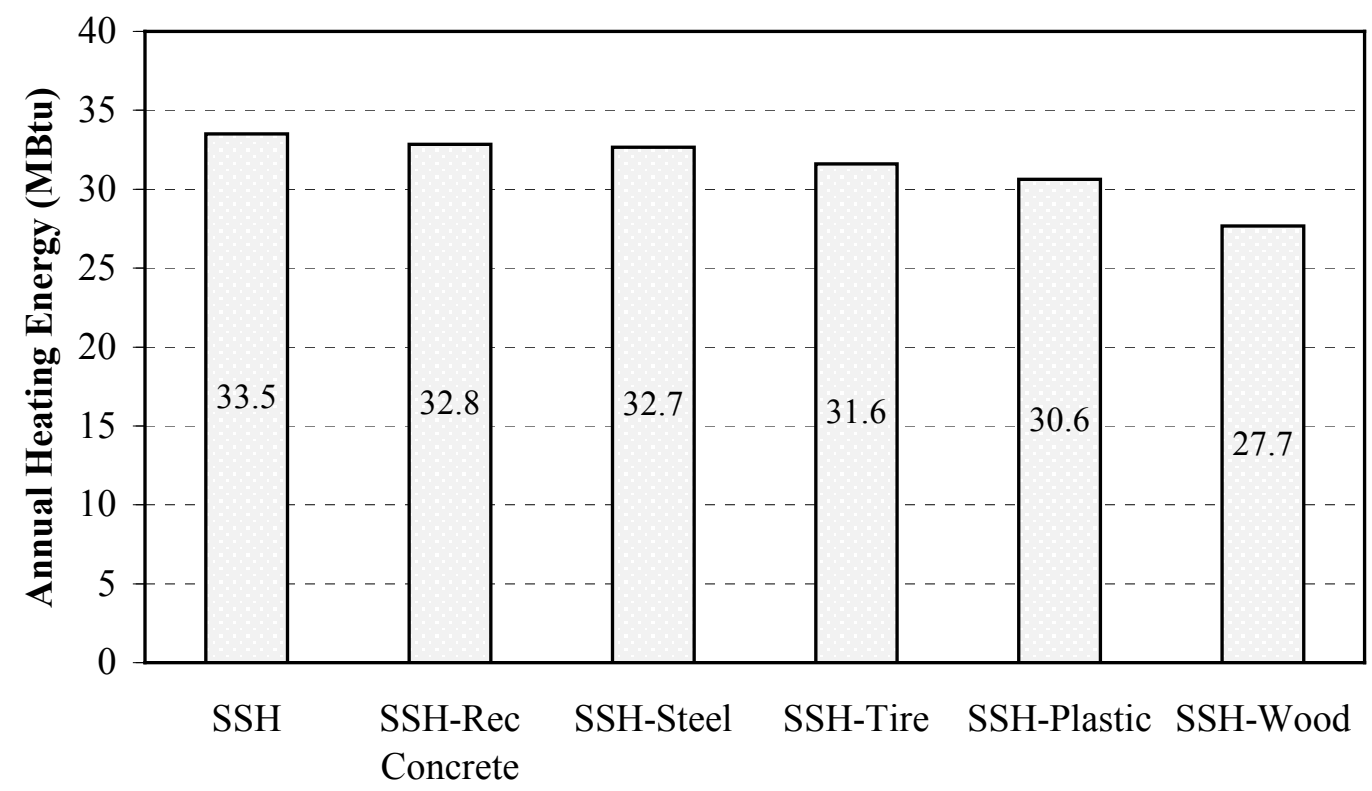

Figure 2. Effect of concrete type on annual heating energy for a small office building in Lansing, Michigan

Figure 3 shows the effect of concrete-specific heat on building energy performance. The curves were created by varying the specific heat while maintaining a constant thermal conductivity in a building with an economizer cycle and the proposed insulation levels as listed in Table 1. The two concrete types used in the buildings contained in this report are marked on the graph. A building using concrete with a specific heat near zero would have double the energy load of the proposed building. Construction materials with a low specific heat are considered lightweight and have poor thermal capacitance, which lowers the building's ability to store heat. Heat capacity acts as a reservoir that stores excess heat when the building is hot and releases it later when the building is cooler. This tends to smooth the peak loads and can reduce overall heating and cooling energy requirements. A large heat capacity is especially important for buildings with high solar gains to help prevent overheating during the day and to help keep the building warm at night by slowly releasing the stored energy. 


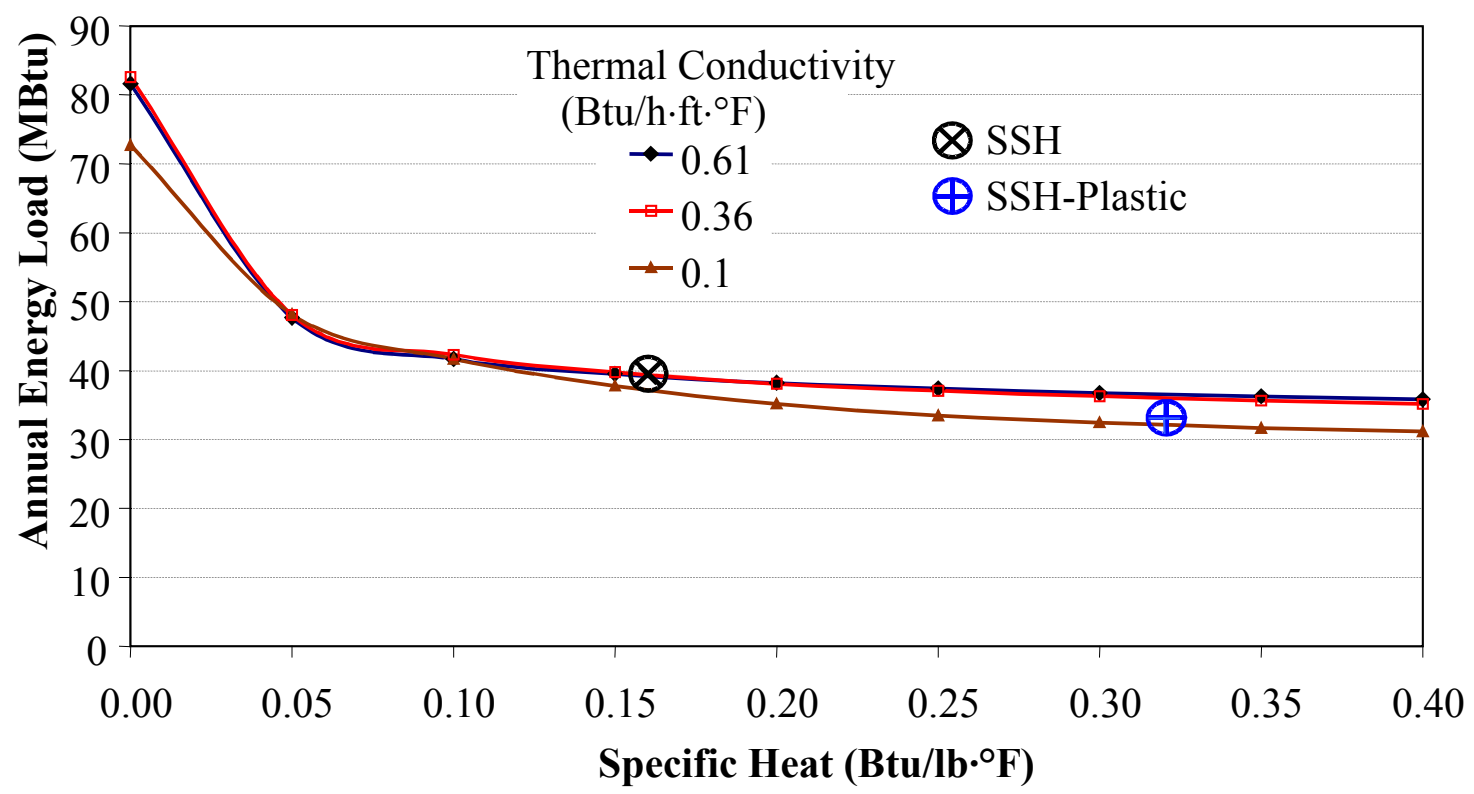

Figure 3. Effect of concrete-specific heat on the annual building energy load

The effect of the concrete's thermal conductivity on building heating and cooling energy is presented in Figure 4 . The graph was produced by varying the thermal conductivity for three specific heat values. A lower thermal conductivity results in a lower energy load. When the thermal conductivity is near zero, almost no heat is lost through the walls, floors, and ceilings. All the heat loss can be attributed to infiltration, window heat loss, and outside air requirements. As the thermal conductivity of the concrete increases, the insulation becomes the dominant thermal resistance and the curves level off.

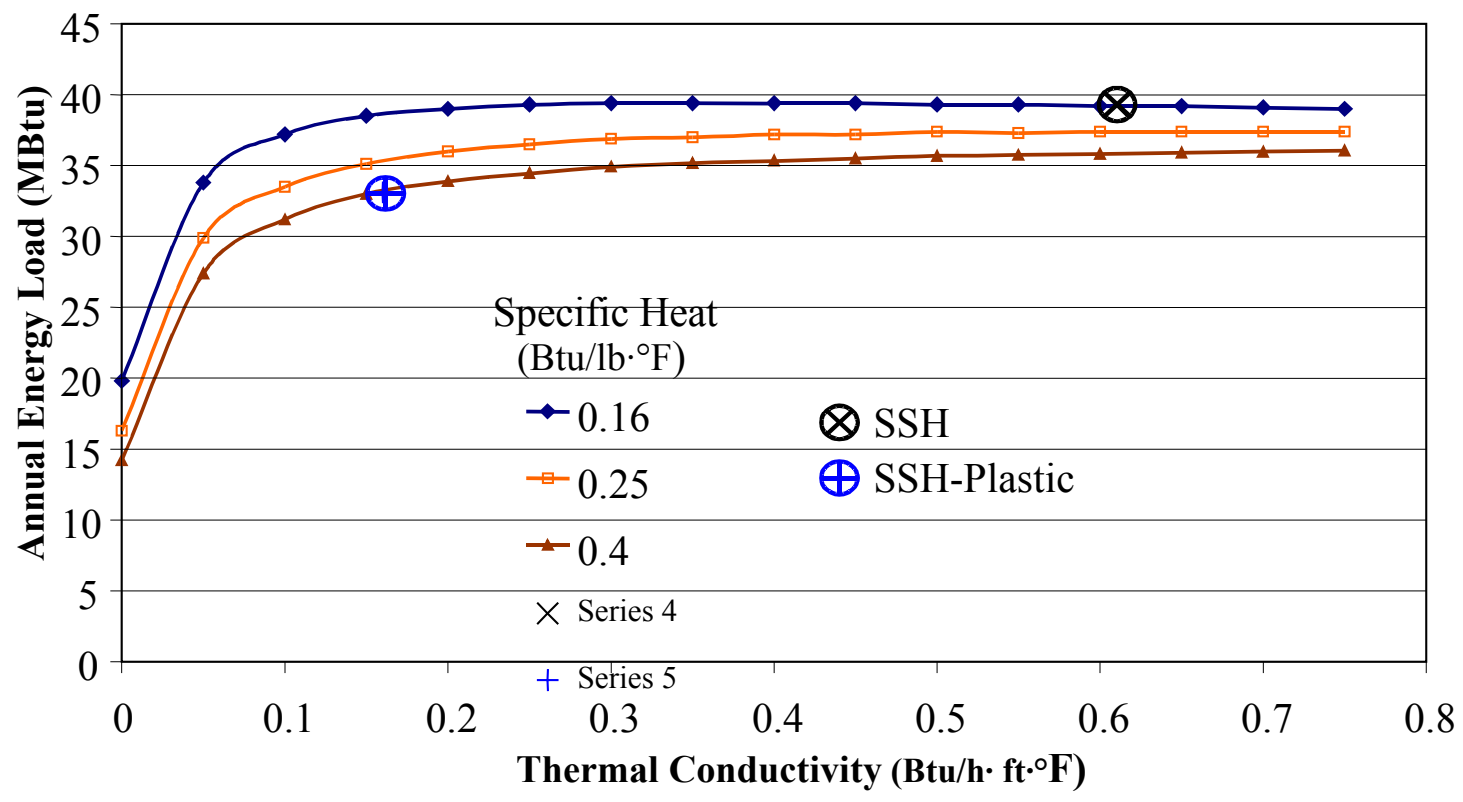

Figure 4. Effect of concrete thermal conductivity on the annual building energy load

The effect of the insulation level on the exterior walls is shown in Figure 5 for each concrete type. The results for the SSH-recycled concrete are almost identical to the SSH concrete, so they are not included in the figure. The graph was produced by varying the insulation and concrete type of the walls while keeping 
all other parameters constant. SSH concrete was used for the slab, roof, and below-grade walls for all runs. Only the aboveground wall concrete was varied. As the thermal resistance of the walls increases, the effects of the concrete become less pronounced. Above insulation values of R-25, the concrete type causes very little difference in building energy performance. The low thermal conductivity of SSH-Wood is evident when the insulation level is low, but as the insulation level increases, the difference in building energy becomes smaller.

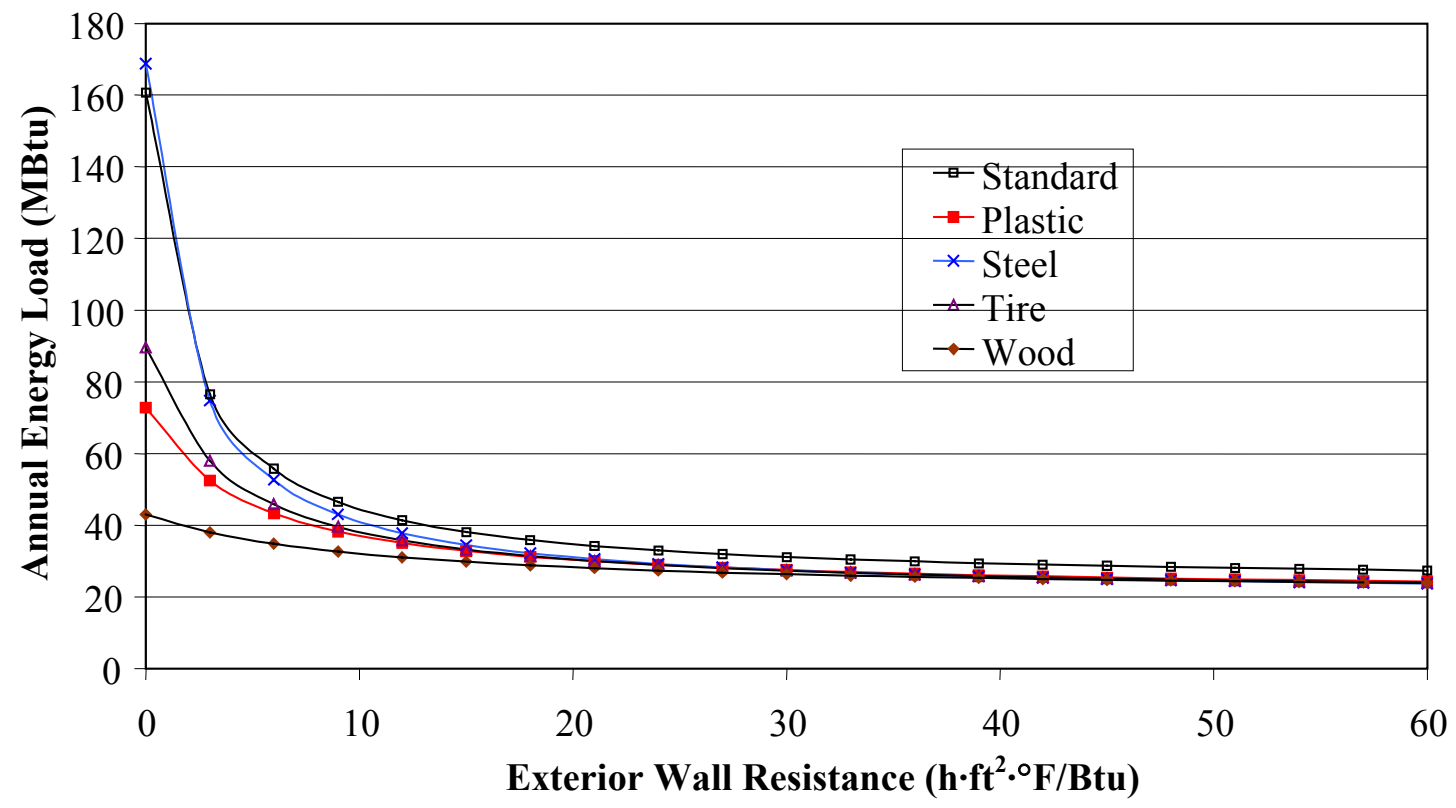

Figure 5. Effect of increased insulation and concrete type on building energy

Figure 6 shows the effect of the concrete wall thickness on the annual heating and cooling energy. The thicker the wall, the smaller the energy load; however, the benefit becomes very small above 6 in $(15 \mathrm{~cm})$. The "economizer" load is the part of the cooling load that can be met by an economizer for this building. If there were no economizer, the load would have to be met by the cooling equipment.

Thermal mass generally has a positive impact on the energy use and comfort level, especially in buildings with high solar gains. The thermal characteristics of the recycled-content concrete make them an excellent choice for passive solar buildings. Section 5.2 explores the effects of mass in different climates using the calibrated energy simulation model for the south building. 


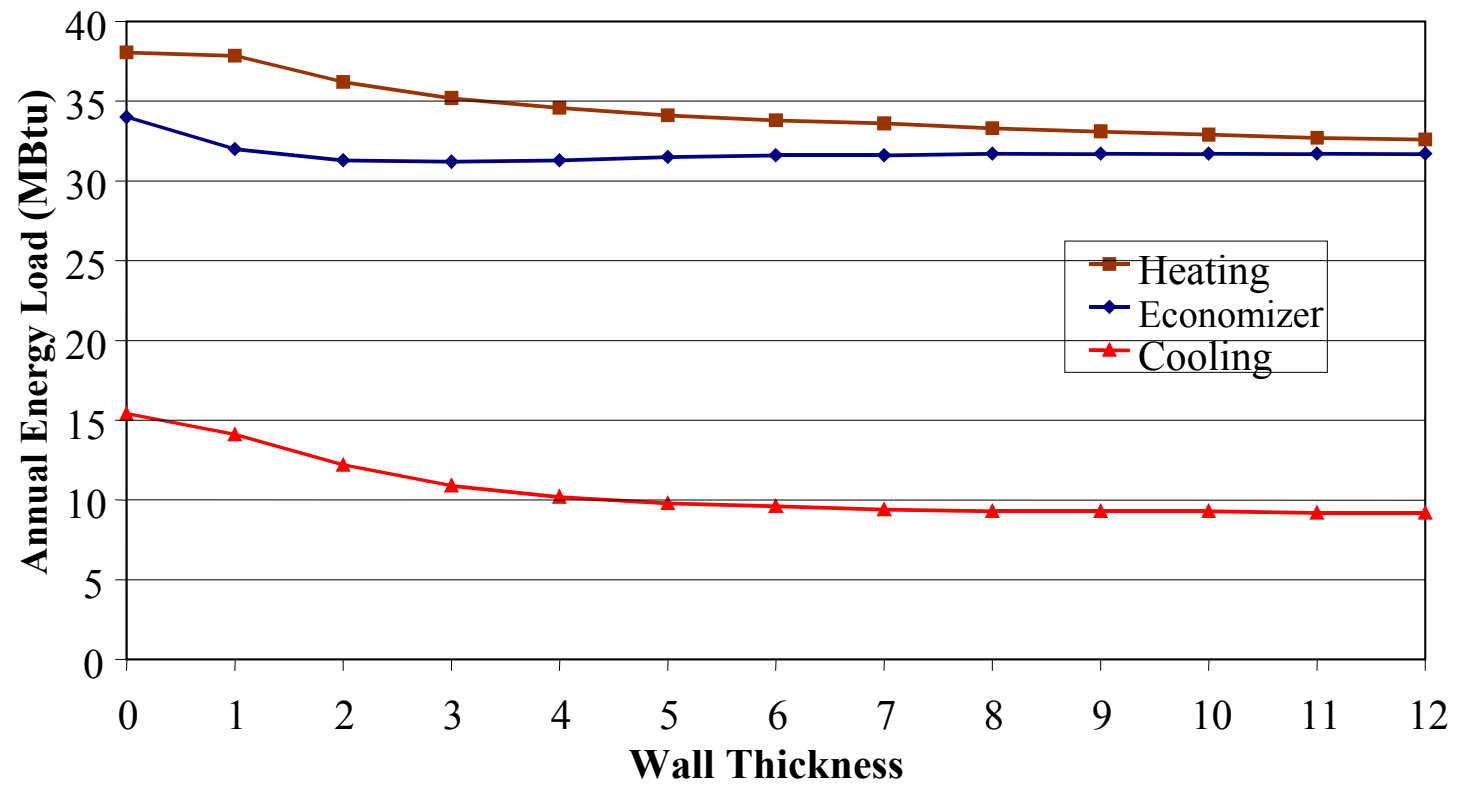

Figure 6. Effect of wall thickness on the building energy load

\section{Monitored Energy Performance}

A short-term energy-monitoring test was performed in April 2000 on the north and south buildings and in July on the south building. Long-term monitoring was performed on the south building from April 2000 to March 2001 to obtain seasonal results under operating conditions; however, the building was unoccupied during this period. Daylighting measurements were taken in the south building in April, July, and December 2000.

\subsection{Short-Term Energy Monitoring Results}

The first short-term test was conducted April 12-19, 2000. Blower door, tracer gas, and co-heating tests were completed at this time in both buildings. A second short-term test was performed July 21-26, 2000 to monitor the performance of the air conditioning system in the south building.

\subsubsection{Air Tightness and Infiltration}

Blower door tests were performed on both buildings. The blower door was installed in the front door of the upper level, and multi-point depressurization tests were conducted. The test is based on the assumption that leakage through a building envelope can be expressed as Equations 1 and 2 [4]. The discharge coefficient, $\mathrm{C}_{\mathrm{D}}$, is usually assumed to be 0.6 ; however, it is set to 1.0 for the purpose of using these equations. The effective leakage area is ELA, the air density is $\rho$, and the pressure difference across the building envelope is $\Delta \mathrm{P}$. The flow coefficient, $\mathrm{C}$, and the flow exponent, $\mathrm{n}$, are determined from the depressurization tests, and the ELA is determined by equating the following two equations:

$$
\begin{aligned}
& \mathrm{Q}=\mathrm{C}_{\mathrm{D}} \operatorname{ELA} \sqrt{2 \Delta \mathrm{P} / \rho} \\
& \mathrm{Q}=\mathrm{C} \Delta \mathrm{P}^{\mathrm{n}}
\end{aligned}
$$


The results of the blower door tests are shown in Table 3. The south building has a higher measured ELA; however, both buildings are relatively tight. One reason for the difference may be that the exterior stucco had not been applied to the south building when the tests were conducted.

Table 3. Blower Door Test Results

\begin{tabular}{|l|c|c|}
\hline & South & North \\
\hline \hline ELA (in ${ }^{2}$ @ 4 Pa, & 104 & 71 \\
\hline CFM@ 50 Pa & 1470 & 1047 \\
\hline C & 171.5 & 114.8 \\
\hline $\mathrm{N}$ & 0.548 & 0.565 \\
\hline
\end{tabular}

Tracer gas tests were started in both buildings on Thursday, April 13 at 6:00 p.m. and ended on Wednesday, April 19 at 6:00 a.m. (see Figure 7). The date on the graph marks the beginning of the day (12:00 a.m.). This test determines the net air-exchange rate between the inside and outside air measured in air changes per hour (ACH). For these tests, tracer gas was injected and sampled only in the upper-floor volumes of both buildings; therefore, air flowing from the lower floor to the upper floor would be measured as outside air. The multi-zone air-exchange rates with the equipment and techniques used in these tests could not be determined. This test also shows that the north building had less leakage than the south building.

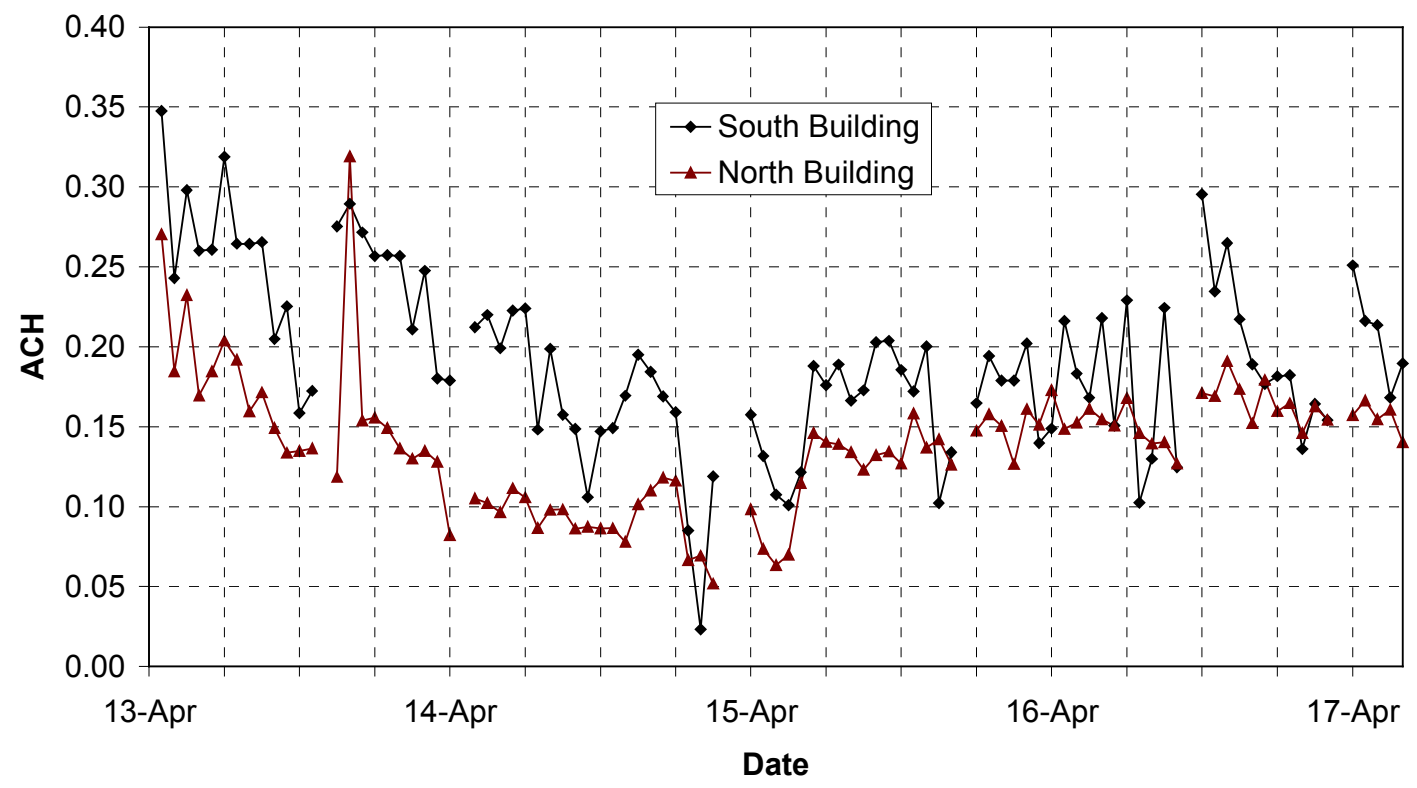

Figure 7. Tracer gas measurements of air changes per hour (ACH) from April 13 to April 17

\subsubsection{Co-Heating Test Results}

Both buildings were heated with portable electric heaters from Thursday, April 13 to Tuesday, April 18 to enforce a constant and uniform interior temperature set point while accurately measuring the energy required to maintain the set point. The information from this test is used to directly compare the relative energy performance of the two buildings and to help calibrate the computer simulations of the energy performance. 
The weather conditions during the co-heating period are shown in Figure 8. April 14, 15, and 18 were relatively warm and sunny, while April 16 and 17 were cool and cloudy.

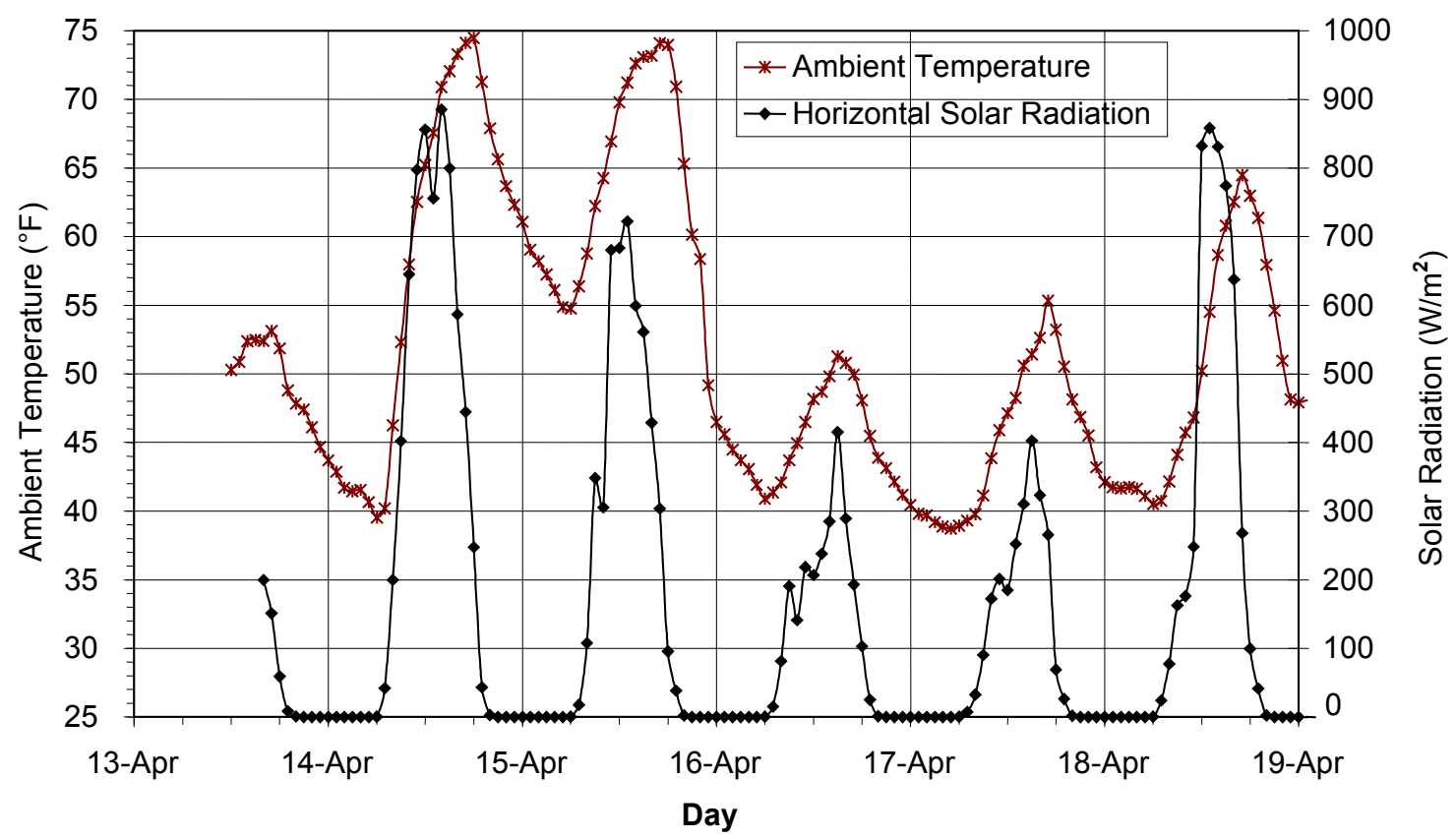

Figure 8. Ambient temperature and global horizontal solar radiation during the co-heating period

The interior temperatures were measured at six locations in each building during the co-heating test. The averages of these six temperatures from each building are compared in Figure 9. High solar gains caused the temperature in both buildings to rise above the set point on April 14 and 15. (The north building is partially shaded by the south building and therefore stays cooler during the day.) The temperatures remained relatively stable on April 16 and 17. The temperature in the north building on the morning of April 17 dropped below the heating set point because the losses were greater than the capacity of the heaters. The temperatures diverged during the evening of April 18 because the building furnace in the south building turned on. 


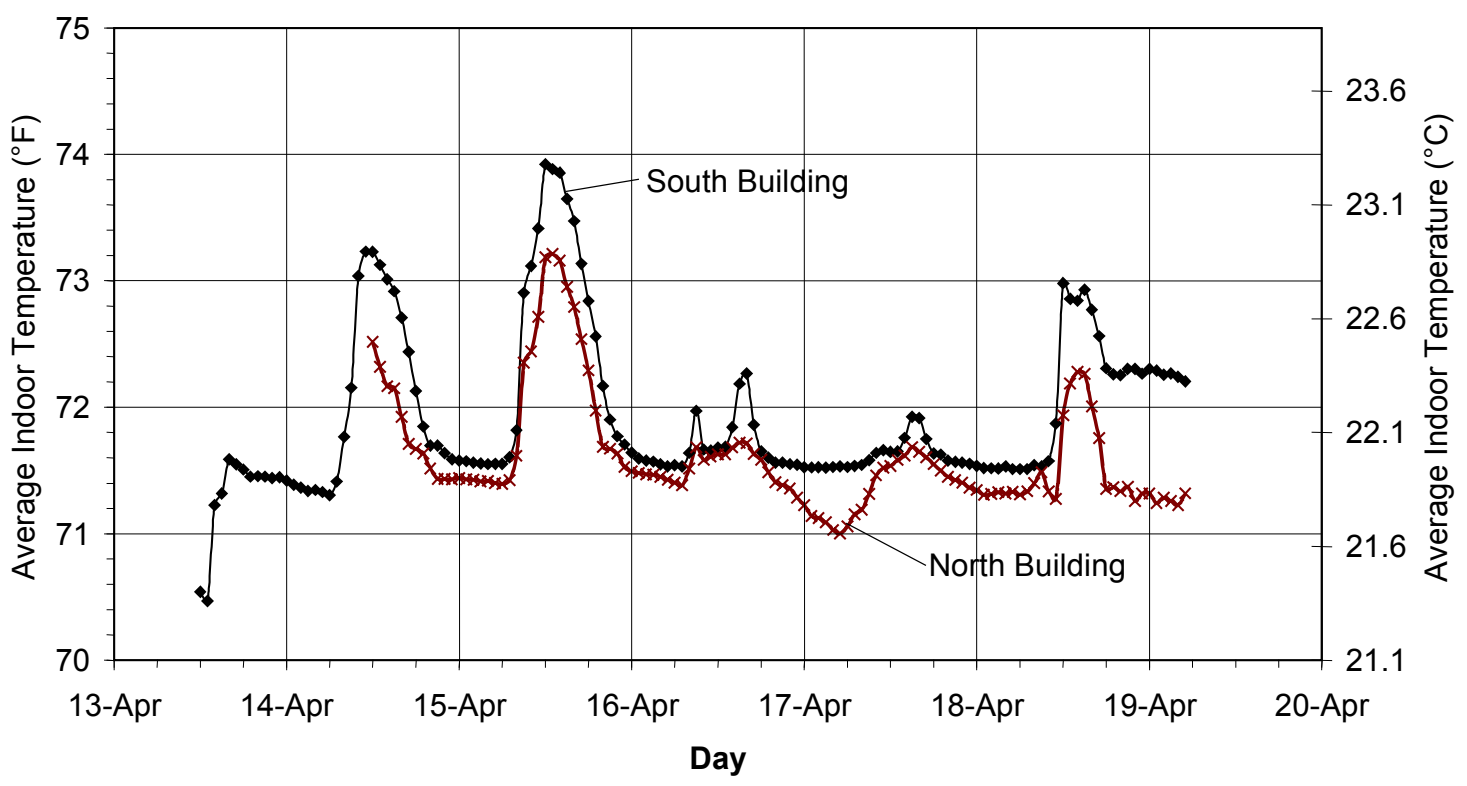

Figure 9. Average interior temperatures during the co-heating test

Figure 10 shows the electric power required for heating in both buildings during the co-heating period. The north building consistently uses about $25 \%$ more power than the south building because it has a higher overall building loss coefficient and a lower solar gain due to shading by the south building.

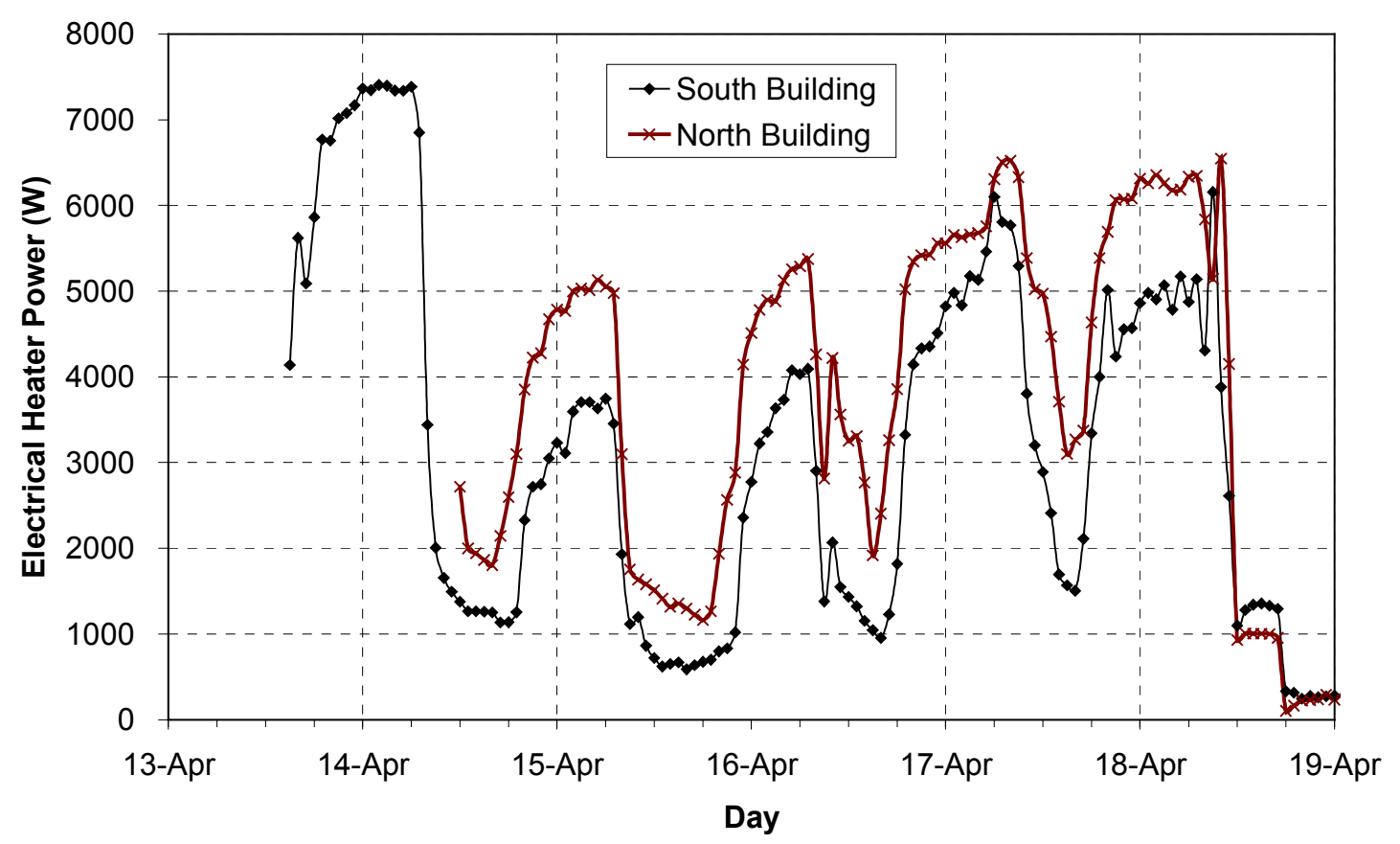

Figure 10. Comparison of electric power use in both buildings during the co-heating period

\subsubsection{Air Conditioning System Performance}

The performance of the air conditioning systems in the south building was tested from July 20-28, 2000. During the tests, the indoor air temperatures were measured, the electric power was monitored, and tracer 
gas measurements were taken. The air-conditioning system on the main floor has an economizer, which is enthalpy controlled with four settings (A-D). The system responds to both outside dry-bulb temperature and relative humidity to determine when to use outside air for cooling. The manufacturer's curves for the four economizer settings, along with the measured temperature and relative humidity for each hour in July 2000, are shown in Figure 11. For points to the left of the curve, the economizer dampers are open and the mechanical air conditioner is off. When the conditions are to the right of a curve, the economizer dampers are closed to the minimum outside air setting and the mechanical air conditioner provides the cooling. The air conditioning system for the basement does not have an economizer.

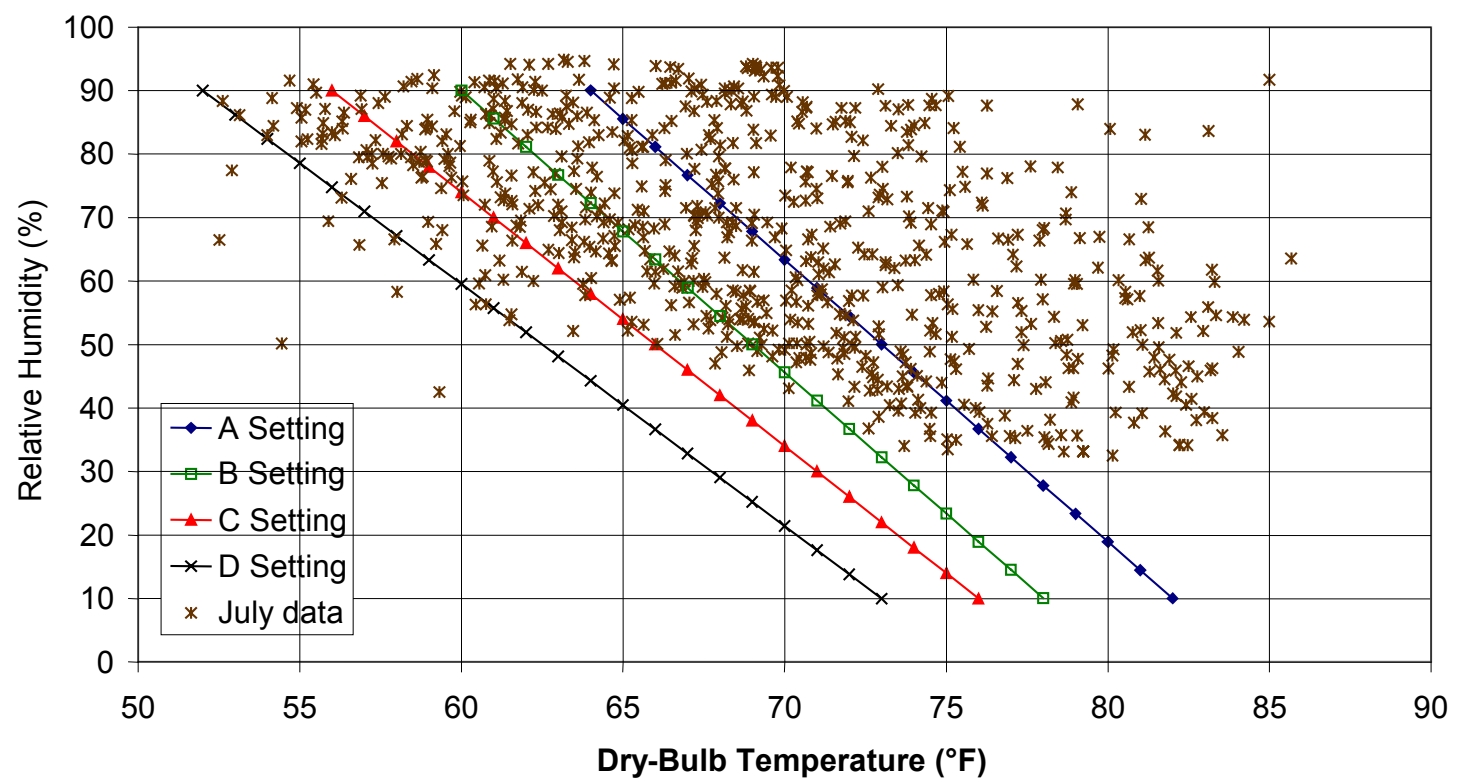

Figure 11. Economizer control with temperature and relative humidity data for July 2000

The ambient temperature during the testing period is shown in Figure 12. From July 20-23, the temperature is moderate, never exceeding $77^{\circ} \mathrm{F}\left(25^{\circ} \mathrm{C}\right)$, and slowly warming to a maximum of $86^{\circ} \mathrm{F}$ $\left(30^{\circ} \mathrm{C}\right)$ on July 27 . The relative humidity follows the same pattern during the testing period. 


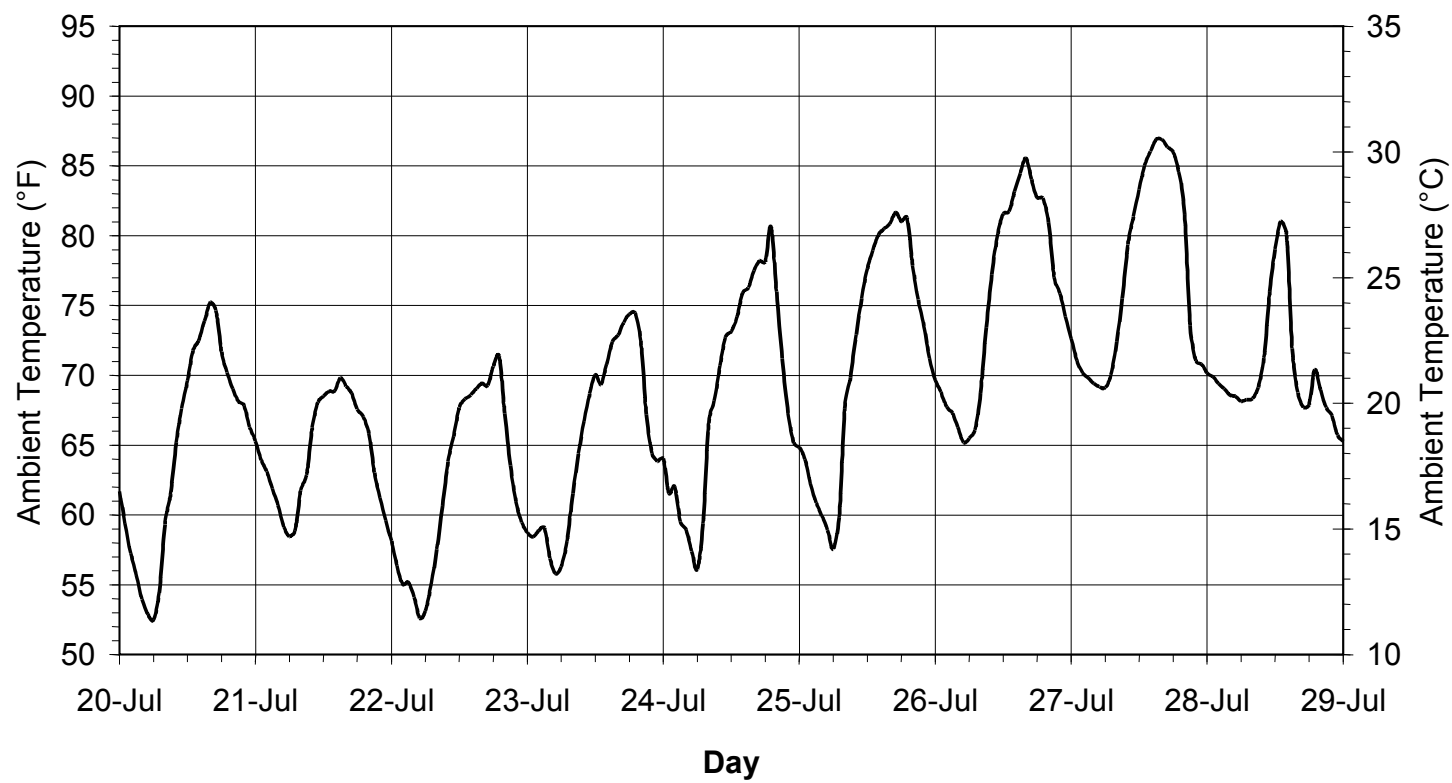

Figure 12. Ambient temperature during the air conditioning system test period

The system was operated in two modes to determine the effectiveness of each. In the first test from July 20-23, the upper-floor system was operated with the economizer in the A setting with a cooling set point of $70^{\circ} \mathrm{F}\left(21^{\circ} \mathrm{C}\right)$, and the lower-floor system was turned off. On July 24 , the economizer was set on D, and both systems were set up with cooling set points of $75^{\circ} \mathrm{F}\left(24^{\circ} \mathrm{C}\right)$ and heating set points of $68^{\circ} \mathrm{F}\left(20^{\circ} \mathrm{C}\right)$. The indoor temperatures during the air conditioning test period are shown in Figure 13. The electrical power for the air conditioning systems and the lights for both floors are shown in Figures 14 and 15. The electric lights were turned on for lighting tests on the evening of July 23 and were left on for most of the time until the evening of July 25.

During the first half of the test, the indoor temperatures were maintained within an acceptable comfort range with only the economizer operating, except for late in the afternoon on July 23 when the air conditioning unit came on briefly. There were no internal gains during this period that would have added to the cooling load. During the second test, with the economizer in the D setting, only the economizer operated in the evenings and early mornings of July 23 and July 24, when the lights were on all night. During the remainder of the period, the mechanical air conditioning equipment met the cooling load for the main floor. The basement air conditioner came on for approximately two hours when the lights were off. Thus, the basement remains comfortable during relatively warm days with no cooling; however, this may change with internal loads such as lights and people. The average electrical power consumption for cooling the main floor was $1.0 \mathrm{~kW}$ for the first test period and $1.6 \mathrm{~kW}$ for the second period. 


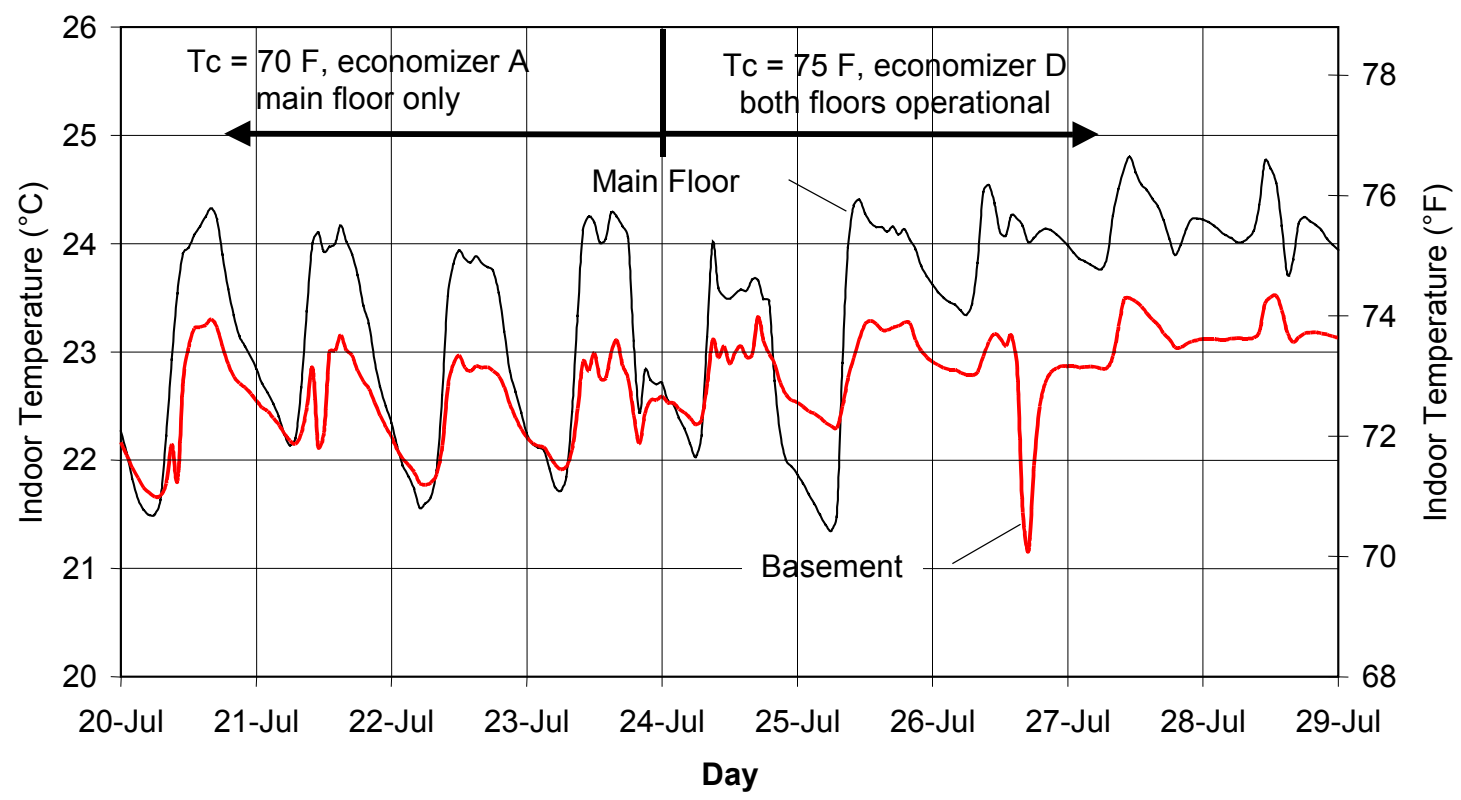

Figure 13. Indoor temperatures during air conditioning test period

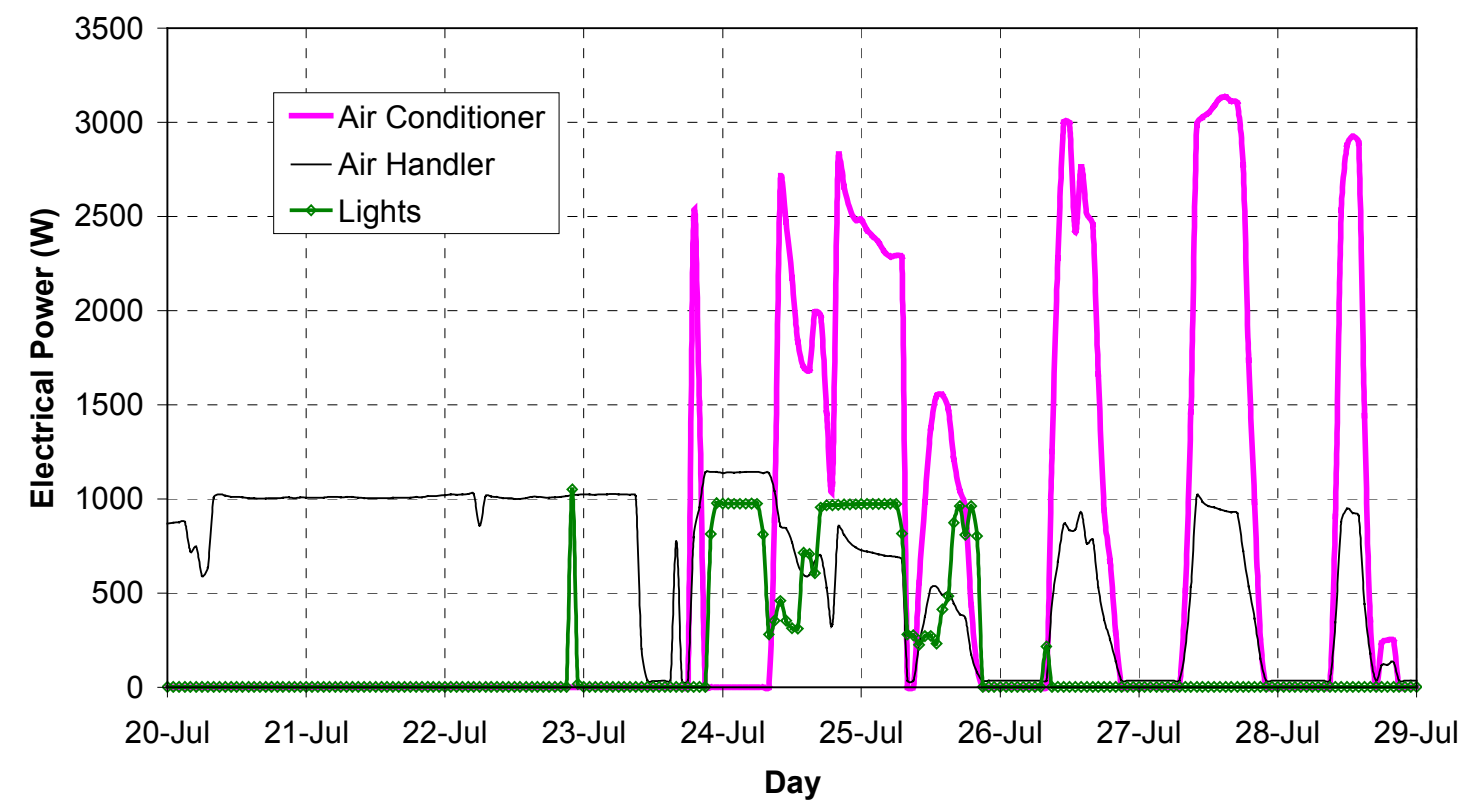

Figure 14. Electrical power used for air conditioning the main floor during the test period 


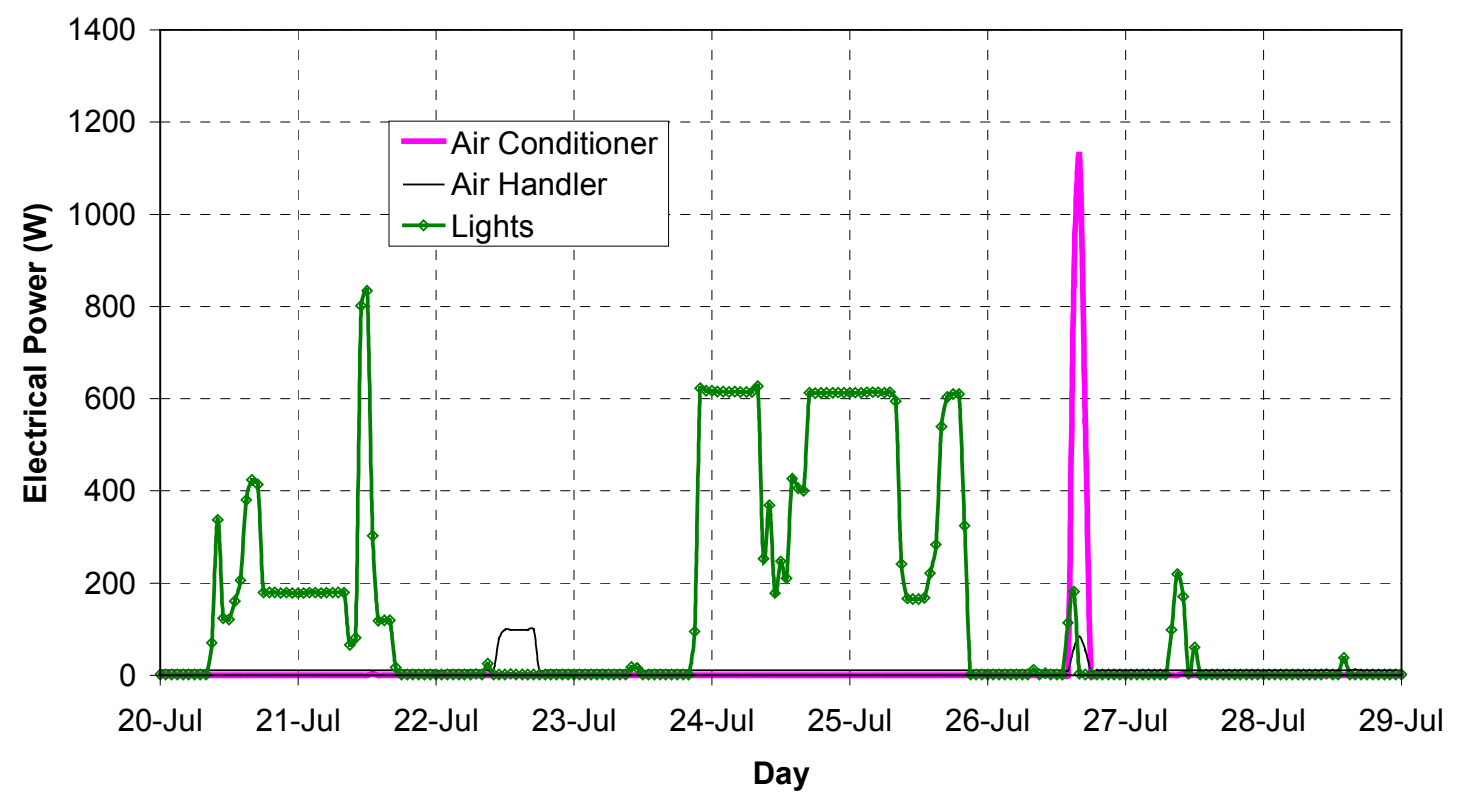

Figure 15. Electrical power used for air conditioning the basement during the test period

Tracer gas tests were conducted during parts of the air conditioning test to monitor the air-exchange rates with the results shown in Figure 16. Insufficient mixing of the air and the limitations of the test equipment caused the tracer gas test readings to be erratic when the economizer operated on July 22 and 23 . The best approximation is that the economizer produces an average of $1.2 \mathrm{ACH}$, which corresponds to $360 \mathrm{cfm}$ of outside air. The air handler requires about $1 \mathrm{~kW}$ of power to produce this flow rate, which is relatively inefficient. During the mechanical air conditioning system operation (without economizer), the system provides 0.1-0.2 ACH, or 30-60 cfm of outside air. ASHRAE Standard 62-1999 [6] states that the minimum outside airflow for acceptable indoor air quality is $15 \mathrm{cfm}$ per person for a retail area and 20 $\mathrm{cfm}$ per person for an office. Therefore, the building may need to have additional outside air during operation with no economizer.

\subsection{Long-Term Monitoring Results}

The purpose of the long-term monitoring was to observe the building performance with seasonal variations under normal operating conditions. The south building was monitored from April 2000 to March 2001. The building was unoccupied during the entire testing period, which enabled various control strategies to be applied and made it easier to compare with computer simulations. However, the unoccupied building situation does not indicate energy use under actual operating conditions. The data points monitored are shown in Table 4. 


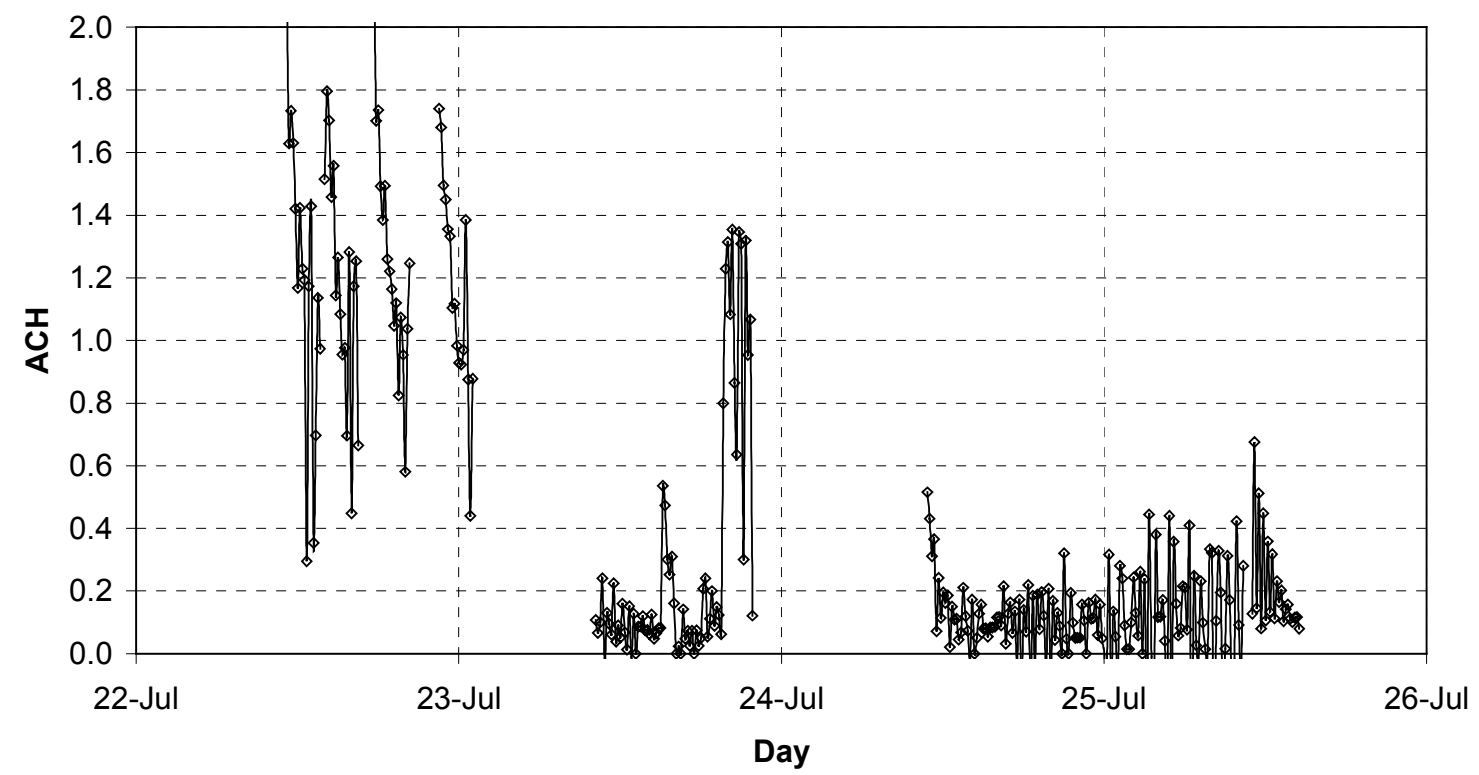

Figure 16. Air-exchange rates for the main floor during the air conditioning test

Table 4. Data Points for Long-Term Energy Monitoring of the South Building

\begin{tabular}{|r|l||r|l|}
\hline No. & Description & No. & Description \\
\hline 1 & Site code & 19 & Lower floor air temperature $\left({ }^{\circ} \mathrm{C}\right)$ \\
\hline 2 & Year & 20 & Lower floor air temperature $\left({ }^{\circ} \mathrm{C}\right)$ \\
\hline 3 & Day of year & 21 & TC outside air temperature $\left({ }^{\circ} \mathrm{C}\right)$ \\
\hline 4 & Hour & 22 & Horizontal irradiance on roof $\left(\mathrm{W} / \mathrm{m}^{2}\right)$ \\
\hline 5 & Battery voltage $(\mathrm{VDC})$ & 23 & Vertical south irradiance at roof line $\left(\mathrm{W} / \mathrm{m}^{2}\right)$ \\
\hline 6 & TC reference temperature $\left({ }^{\circ} \mathrm{C}\right)$ & 24 & Humitter outside air temperature $\left({ }^{\circ} \mathrm{C}\right)$ \\
\hline 7 & T10, floor insulation bottom surface $\left({ }^{\circ} \mathrm{C}\right)$ & 25 & Humitter outside relative humidity $(\%)$ \\
\hline 8 & T11, floor insulation top surface $\left({ }^{\circ} \mathrm{C}\right)$ & 26 & Upper floor total electric power $(\mathrm{W})$ \\
\hline 9 & T12, floor slab center $\left({ }^{\circ} \mathrm{C}\right)$ & 27 & Upper floor air conditioner power $(\mathrm{W})$ \\
\hline 10 & T20, floor insulation bottom surface $\left({ }^{\circ} \mathrm{C}\right)$ & 28 & Upper floor lighting power $(\mathrm{W})$ \\
\hline 11 & T21, floor insulation top surface $\left({ }^{\circ} \mathrm{C}\right)$ & 29 & Upper floor, air-handler power $(\mathrm{W})$ \\
\hline 12 & T22, floor slab center $\left({ }^{\circ} \mathrm{C}\right)$ & 30 & Lower floor, total electric power $(\mathrm{W})$ \\
\hline 13 & $\mathrm{~T} 30$, wall insulation outer surface $\left({ }^{\circ} \mathrm{C}\right)$ & 31 & Lower floor, air conditioner power $(\mathrm{W})$ \\
\hline 14 & T31, wall concrete outer surface $\left({ }^{\circ} \mathrm{C}\right)$ & 32 & Lower floor, lighting and plugs $(\mathrm{W})$ \\
\hline 15 & T33, wall concrete $\left({ }^{\circ} \mathrm{C}\right)$ & 33 & Lower floor, air-handler power $(\mathrm{W})$ \\
\hline 16 & T34, wall concrete $\left({ }^{\circ} \mathrm{C}\right)$ & 34 & Upper floor furnace status \\
\hline 17 & Upper floor air temperature $\left({ }^{\circ} \mathrm{C}\right)$ & 35 & Lower floor furnace status \\
\hline 18 & Upper floor air temperature $\left({ }^{\circ} \mathrm{C}\right)$ & & \\
\hline
\end{tabular}

Points 7-16 in Table 4 are type-T thermocouples installed in the concrete of the basement floor slab and below-grade wall and on both sides of the insulation for these positions. The placement of the thermocouples is shown in Figure 17 with the lowest numbered thermocouple on the exterior and the highest number on the interior. The thermocouples in the wall are located $2 \mathrm{ft}(61 \mathrm{~cm})$ below grade. The contractor installed all thermocouples per instructions from NREL; therefore, their exact locations and spacing cannot be verified. 


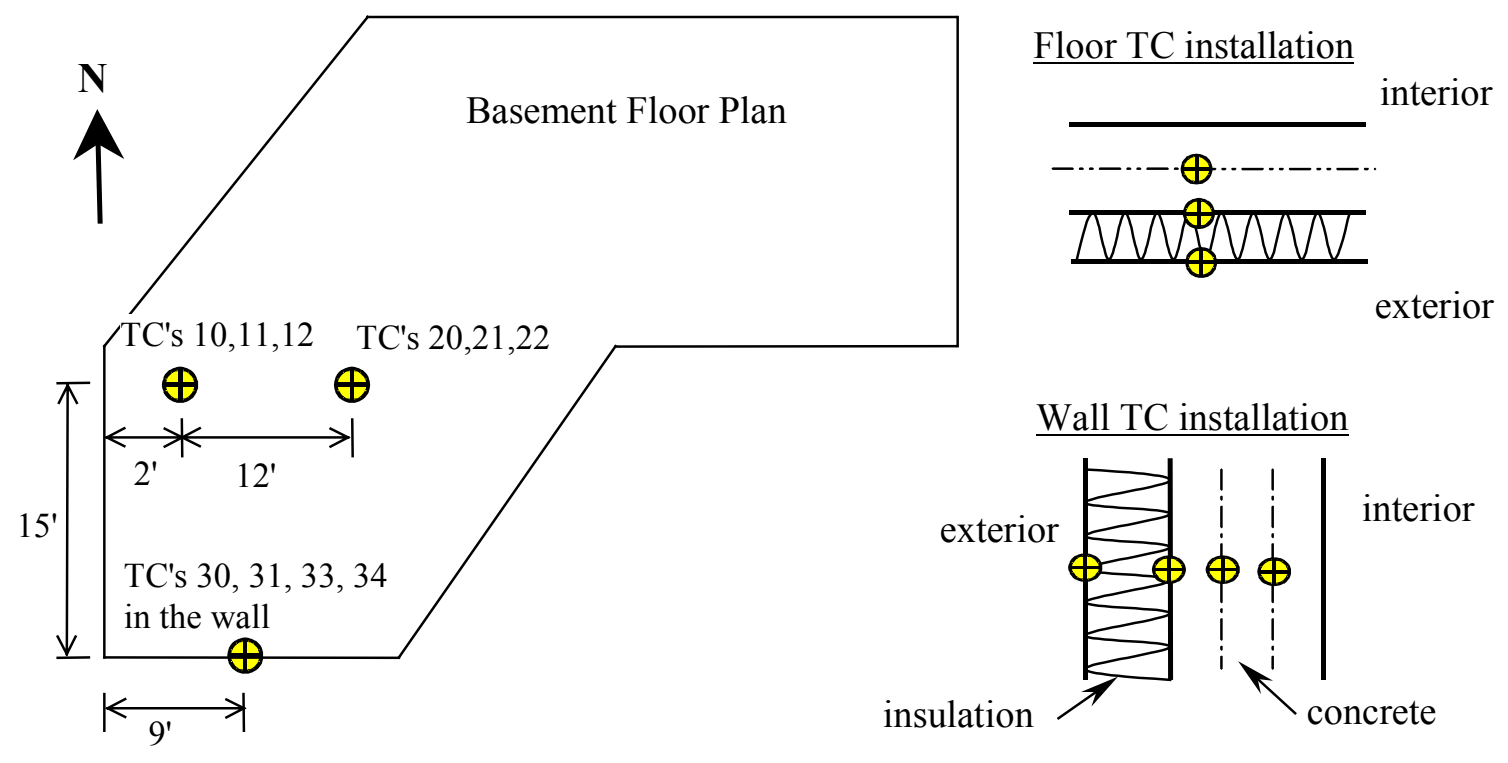

Figure 17. Thermocouple placement for the DPD south building

During the long-term monitoring, the building was operated in various modes: free floating from April 1 to July 19, 2000; constant cooling at $70^{\circ} \mathrm{F}\left(21^{\circ} \mathrm{C}\right)$ with the economizer in setting A from July 20 to July 23; constant cooling $\left(75^{\circ} \mathrm{F}\left[24^{\circ} \mathrm{C}\right]\right)$ and heating $\left(68^{\circ} \mathrm{F}\left[20^{\circ} \mathrm{C}\right]\right)$ set points with the economizer in setting D from July 24 to October 30; free floating from October 31 to December 1 ; and constant cooling $\left(75^{\circ} \mathrm{F}\right.$ $\left.\left[24^{\circ} \mathrm{C}\right]\right)$ and heating $\left(68^{\circ} \mathrm{F}\left[20^{\circ} \mathrm{C}\right]\right)$ set points from December 1, 2000 to March 31, 2001.

The interior air temperatures for part of the monitoring period are shown in Figures 18 and 19. During the free-floating period, the temperatures in the building remained above $44^{\circ} \mathrm{F}\left(7^{\circ} \mathrm{C}\right)$ with no internal heat gains and outside temperatures that dropped to $19^{\circ} \mathrm{F}\left(-7^{\circ} \mathrm{C}\right)$. This shows that the south building has a tight and well-insulated envelope. The basement has much smaller temperature swings during the day and cooled down only to $48^{\circ} \mathrm{F}\left(9^{\circ} \mathrm{C}\right)$ during the free-floating period. The basement has a much smaller window area and has the capacitance and shielding effects of the ground, which makes it more energy efficient than the main floor.

\section{Model Calibration and Predicted Energy Performance}

\subsection{Model Calibration}

The south building is small, has high thermal mass, high solar gains, and a simple HVAC system, so SUNREL was used for computer simulations of energy performance, which were calibrated against the long-term monitoring results. The SUNREL model was compared with the measured building temperatures for the period from October 15 to November 30, 2000. The building was unoccupied during this period, and there are no other internal gains. This represents a period with air conditioning and heating loads from October 15 to October 30 and a free-floating period from October 31 to November 30.

The most significant unknown in the building model is the ground-coupled heat loss. A large part of the building envelope is connected to the ground. SUNREL performs only one-dimensional heat conduction calculations, and the ground heat transfer from the building is three-dimensional. To approximate the heat loss, the underground parts of the building were divided into sections with similar heat transfer characteristics. The only adjustments made to the model were to the amount of soil and fictitious insulation for each underground section. Fictitious insulation is used to model the insulating effect of the 
ground without having to model an extremely thick section of soil and is added as the last layer in the wall or floor. The building has $\mathrm{R}-15 \mathrm{~h} \cdot \mathrm{ft}^{2} \cdot{ }^{\circ} \mathrm{F} / \mathrm{Btu}\left(2.6 \mathrm{~m}^{2} \cdot \mathrm{K} / \mathrm{W}\right)$ exterior insulation on the underground walls and $\mathrm{R}-10 \mathrm{~h} \cdot \mathrm{ft}^{2} \cdot{ }^{\circ} \mathrm{F} / \mathrm{Btu}\left(1.8 \mathrm{~m}^{2} \cdot \mathrm{K} / \mathrm{W}\right)$ exterior insulation on the slab floor. The walls were divided into an upper section within $5 \mathrm{ft}(1.5 \mathrm{~m})$ of the surface and the remaining lower section. The slab floor was divided into a perimeter section $3.8 \mathrm{ft}(1.2 \mathrm{~m})$ wide around the portion of the basement with a half underground wall and the remaining core section. The best agreement was obtained with the following wall and floor sections: The upper wall section was modeled as 8 in $(20 \mathrm{~cm})$ of concrete, R-15 insulation, and $3 \mathrm{ft}(0.9 \mathrm{~m})$ of soil to the AMBIENT conditions; the lower wall section was modeled as 8 in $(20 \mathrm{~cm})$ of concrete, R-15 insulation, and $6 \mathrm{ft}(1.8 \mathrm{~m})$ of soil to the AMBIENT conditions. The slab perimeter was modeled as 6 in $(15.2 \mathrm{~cm})$ of concrete, $\mathrm{R}-10$ insulation, and $6 \mathrm{ft}(1.8 \mathrm{~m})$ of soil to the AMBIENT conditions. The core was modeled with 6 in $(15.2 \mathrm{~cm})$ of concrete, R-10 insulation, $6 \mathrm{ft}(1.8 \mathrm{~m})$ of soil, and an additional fictitious R-10 insulation to the ground temperature. The ground temperature was held constant at $46.8^{\circ} \mathrm{F}\left(8.2^{\circ} \mathrm{C}\right)$, which is the annual average air temperature.

The calibrated model was compared with the measured building data. Figures 18 and 19 show the measured and predicted temperatures for the main floor and the basement from October 16 to December 31. This period includes warm weather with cooling required, a free-floating period, and the building warm-up after the free-floating period. The calculated temperatures from SUNREL match the measured data for both floors very well. The error for the basement becomes slightly larger during the free-floating period. SUNREL did not predict the temperature spikes in December. These are believed to be temperature increases of the wall containing the temperature sensor caused by direct solar gain from the low winter sun angle and not a temperature increases of the entire space.

There are two periods of missing data: one on November 10 and one from December 16-18. The weather data for these times for the SUNREL weather file were obtained from the Michigan State University (MSU) Agricultural Department Web site at: http://www.agweather.geo.msu.edu/AWO/Current/Automated/.

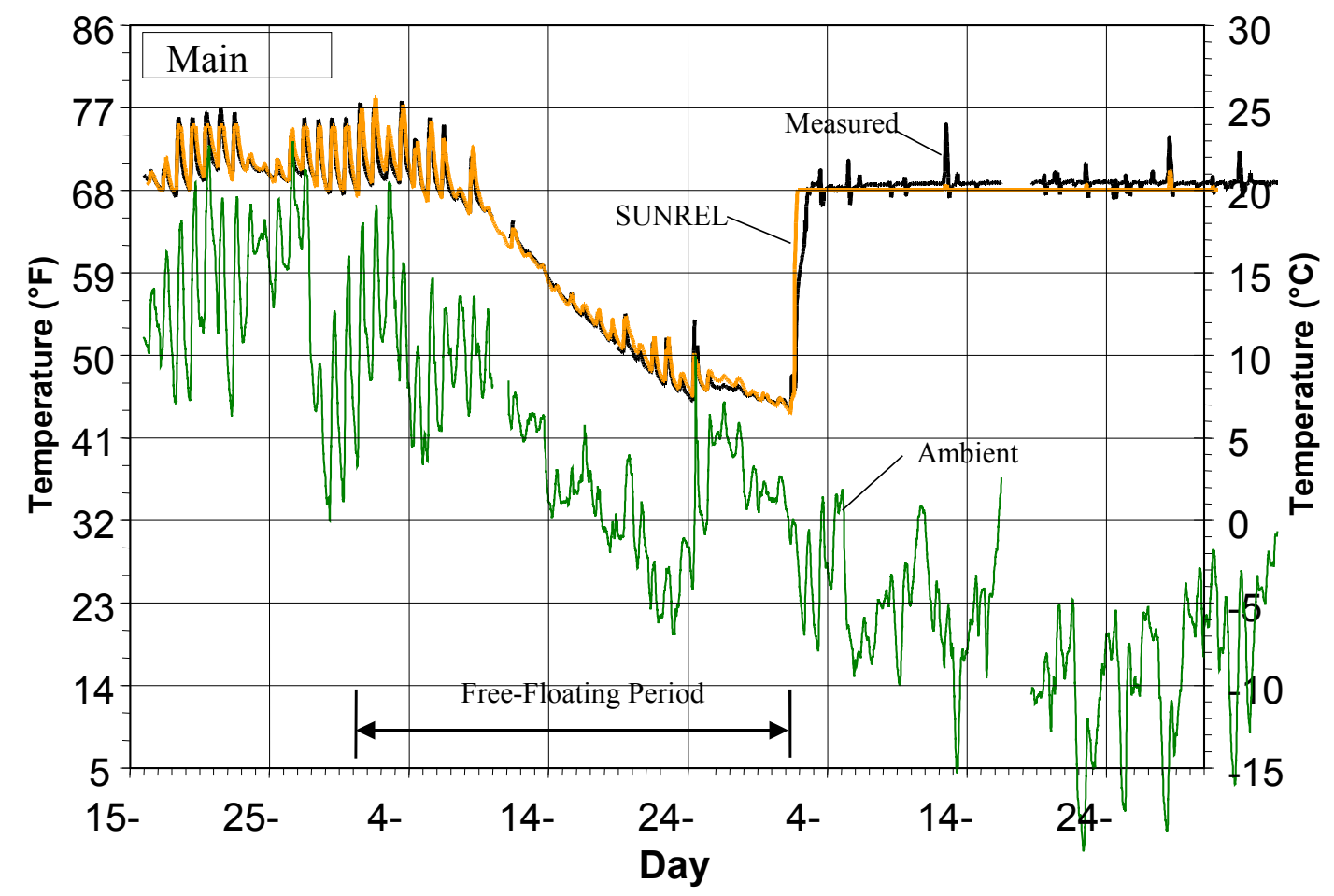

Figure 18. Measured and calculated main-floor temperatures and ambient temperature 


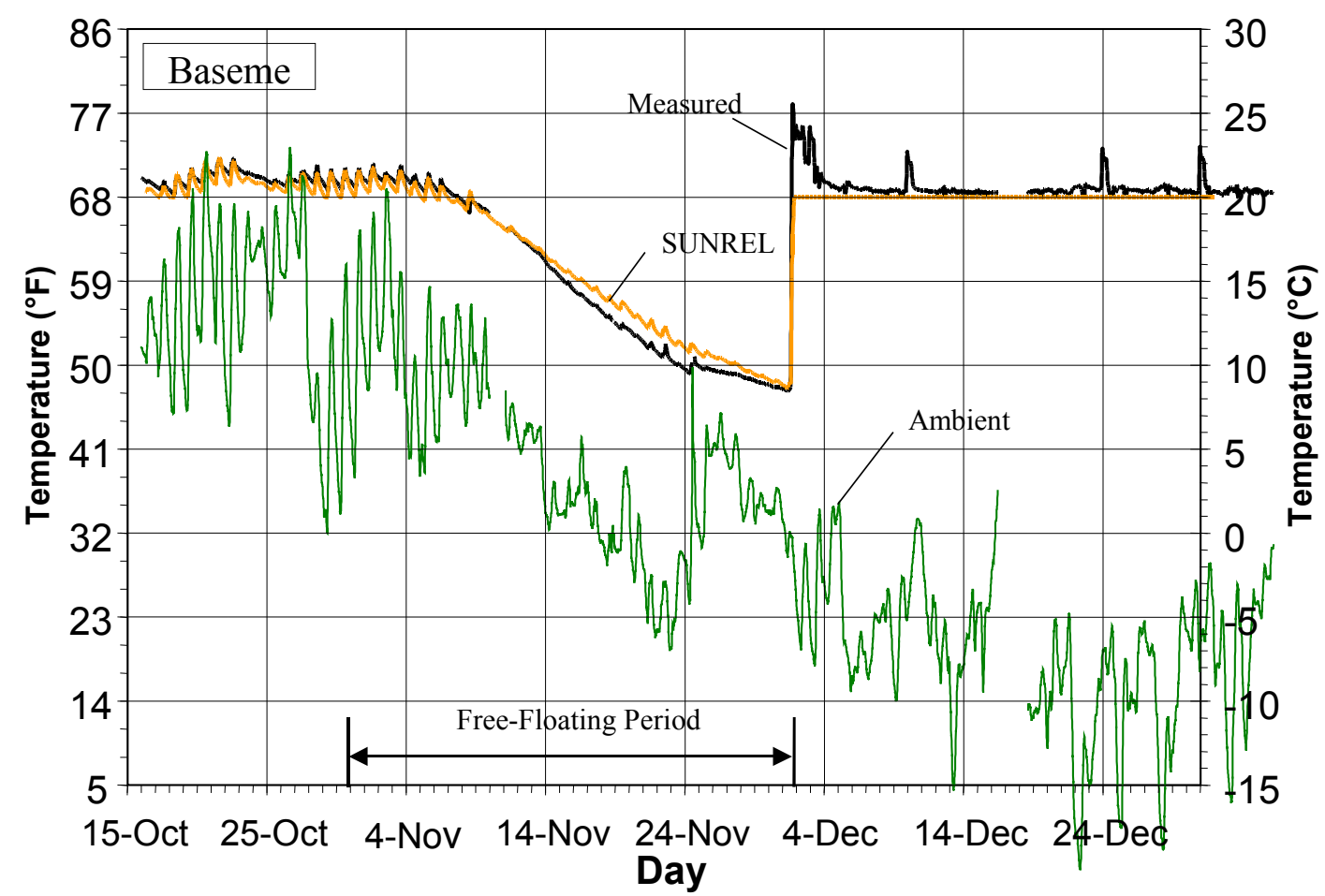

Figure 19. Measured and calculated basement temperatures and the ambient temperature

Comparing the furnace energy input is a bit more difficult for two reasons. First, only the furnace run times (not the gas flow) were recorded. The main-floor furnace runs in high mode; therefore, only this stage of the furnace was monitored. Both stages of the basement furnace were monitored. The furnaces have an efficiency of $94 \%$ AFUE and have high/low ratings of $80 / 52 \mathrm{kBtu} / \mathrm{h}$ for the main floor and $60 / 39$ $\mathrm{kBtu} / \mathrm{h}$ for the basement. The furnaces presumably operate at the rated value whenever they are operating; therefore, the gas input was determined as the product of the rated value and the runtime divided by the AFUE. This is not accurate, but it represents the best numbers with the available data. System inefficiencies probably caused the true numbers to be slightly higher. The second reason is that SUNREL does not model the system performance; it only calculates the load an HVAC system would see. Both furnaces and their ducts are in the basement; therefore, the basement benefits from the losses from the main-floor system. Because SUNREL does not model these system losses, SUNREL would probably under predict the main-floor heating and over predict the basement heating.

The results are much more accurate if the whole building is considered as a single system. The only problem is selecting a system efficiency to use with the SUNREL predictions. An overall system efficiency was selected to match the SUNREL calculations with the measured values. Assuming a system efficiency of $80 \%$, the results are good. Figure 20 shows the total energy input into both furnaces as measured and predicted by SUNREL for December 2000. The energy use was high at the beginning of the month because the furnaces were turned on to warm the building after the free-floating period.

SUNREL under predicts the main-floor heat for the entire month by $27 \%$ and over predicts the basement heat by $765 \%$; however, the total building heat is over predicted by less than $2 \%$. The measured basement heating energy for this test period is about 27 times smaller than the main floor; therefore, a small difference in the predicted heating energy for the basement appears as a large percentage error. 


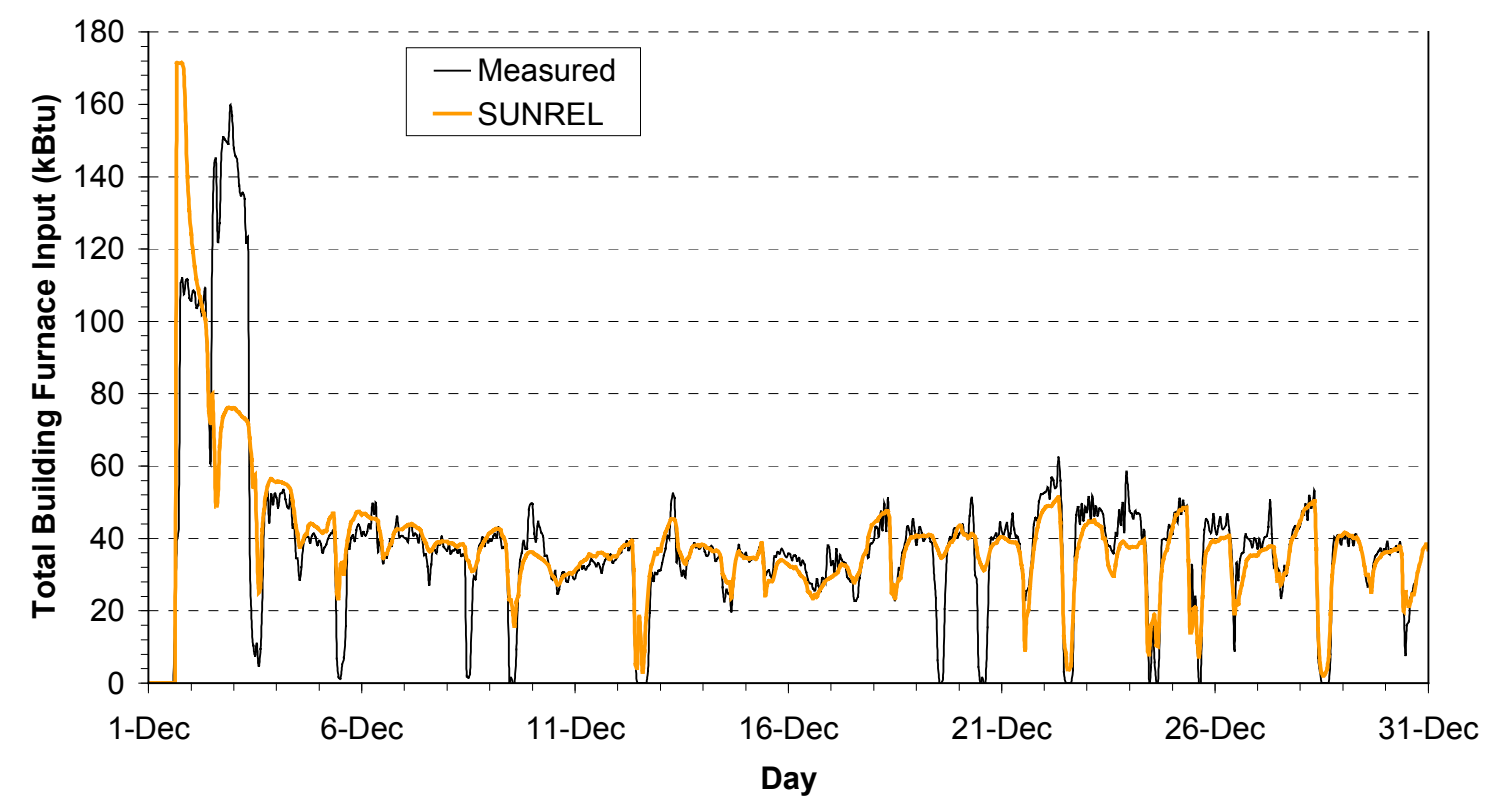

Figure 20. Measured and predicted furnace energy use assuming a system efficiency of $80 \%$

The calibrated building model was compared with the co-heating test results conducted April 13-18 (Section 4.1.2). Because the building model has a high thermal mass content between the concrete and the large amount of soil, it had to be warmed up so the temperatures could reach a quasi-equilibrium.

Weather data for the first two weeks of April were retrieved from the MSU Web site. SUNREL can also run the model for a certain number of days using the weather data from the first day of the weather file. This warm-up period was set to 30 days, when the heating set point was set to $68^{\circ} \mathrm{F}\left(20^{\circ} \mathrm{C}\right)$ until April 12 and then turned off until the beginning of the co-heating test.

During the co-heating test period, a $14.5 \mathrm{kBtu} / \mathrm{h}(7500 \mathrm{~W})$ electric heater was placed on the main floor and a $11 \mathrm{kBtu} / \mathrm{h}(3200 \mathrm{~W})$ electric heater was placed in the basement. The heaters were enabled at 12:00 p.m. on April 13 with a constant heating set point of $71.6^{\circ} \mathrm{F}\left(22^{\circ} \mathrm{C}\right)$. The calibrated SUNREL model used the same heater capacities assuming system efficiency of $100 \%$. Figure 21 shows a comparison of the average of three measured temperatures and the SUNREL temperatures for each floor. The results of the simulations match the measured results well. For the main floor, SUNREL did not capture all the peaks, and the response lagged behind the actual building. At the end of the day on April 18, the building furnace came on and kept the main-floor temperature higher than the SUNREL value. 


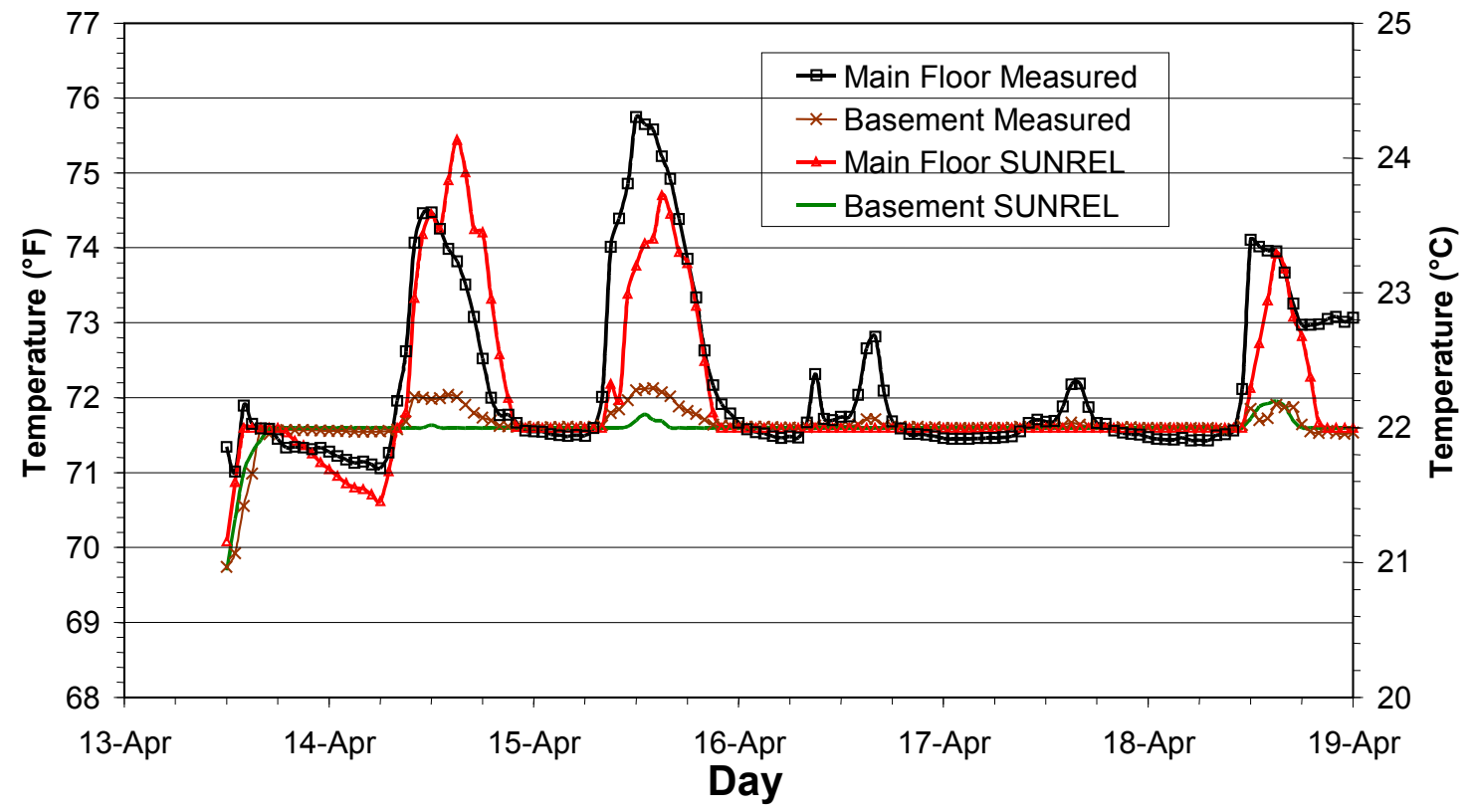

Figure 21. Measured and predicted temperatures during the co-heating test

The measured and predicted heater energy for both floors is shown in Figure 22. The magnitudes and the time responses are very similar for each case. The heaters in the SUNREL case are on much higher at the end of the day on April 18, when the main-floor furnace came on in the building. The total heat input during the co-heating test period, excluding the last four hours of April 18, is shown in Figure 23. SUNREL over predicts the heat input for the main floor by $19 \%$ and under predicts it for the basement by $17 \%$; however, the total building over prediction is only $2 \%$ higher. The differences between the main floor and basement are due to inaccuracies in modeling the local weather conditions, the interzone heat transfer, the building heat losses, and heat capacities.

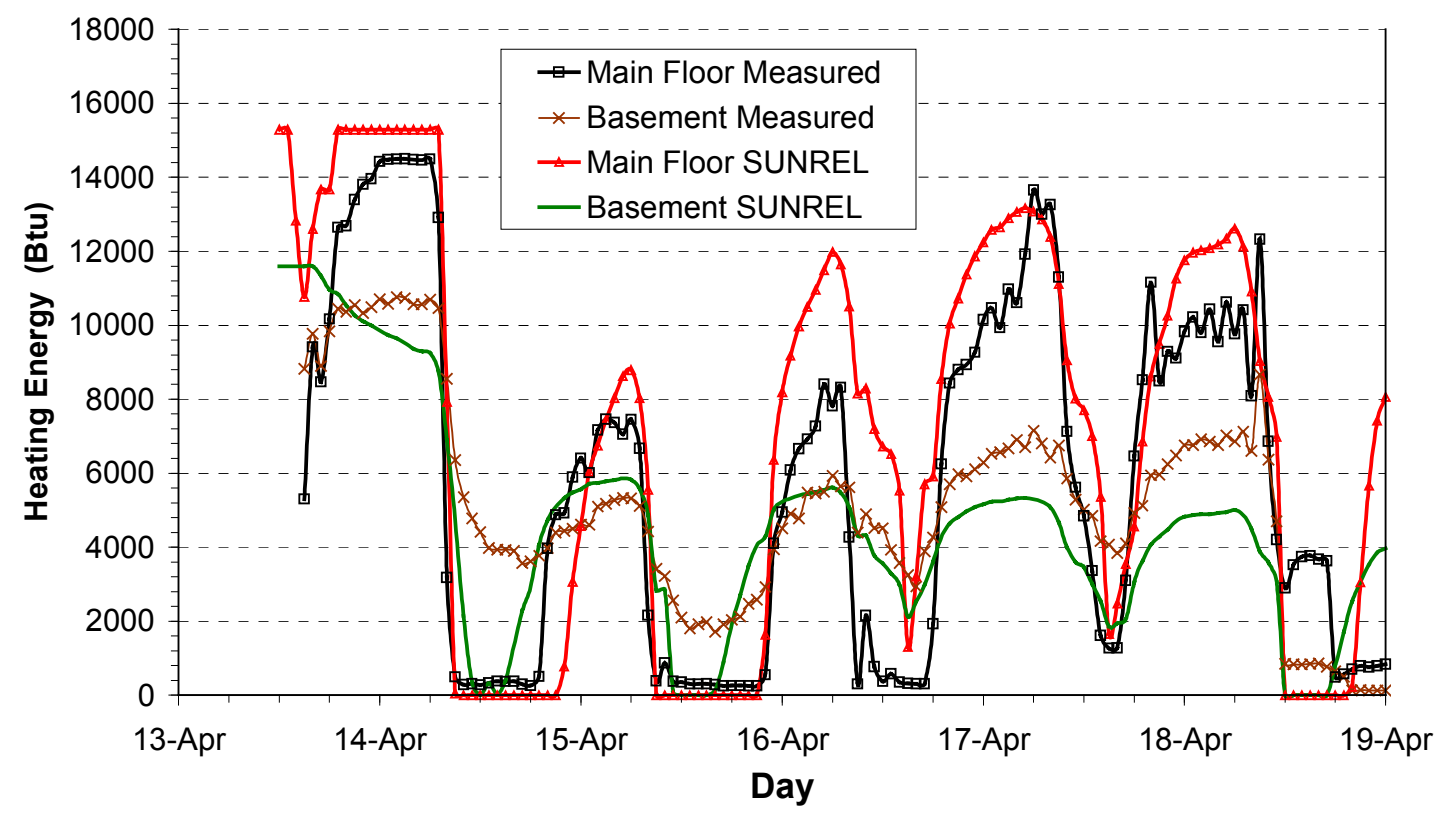

Figure 22. Measured and predicted heating energy during the co-heating test 


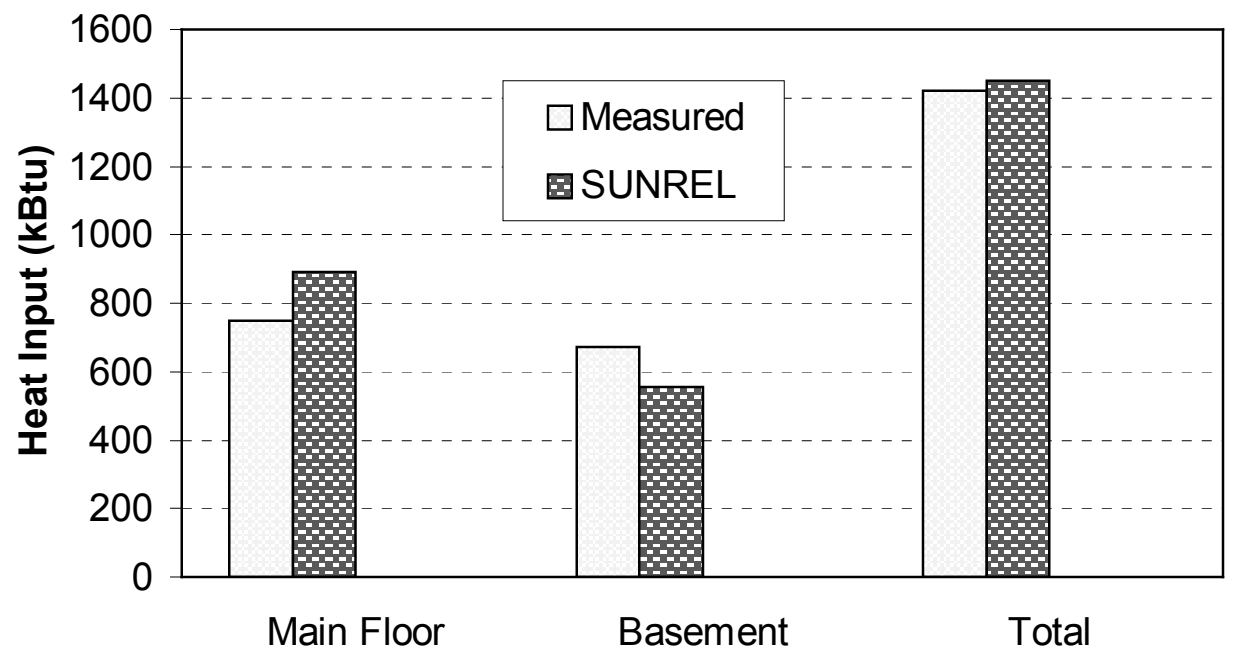

Figure 23. Total building measured and predicted heating energy during the co-heating test

The comparisons with the measured data show that the calibrated SUNREL model can accurately predict overall energy use. SUNREL was within $2 \%$ of the heating energy use for the long- and short-term energy monitoring periods. The temperatures in the spaces can also be predicted accurately (see Figures 18 and 19). With the calibrated model, simulations can be performed with more confidence to estimate energy performance with different concrete types and control strategies.

Matching the performance of the air conditioning system with SUNREL is much more difficult than with the heating system. SUNREL does not model the use of a dead band and performs simple calculations for the latent energy. The economizer on the main floor can be approximated as controlled venting to the ambient. Therefore, the predictions of the cooling energy will not be as good as for the heating energy.

\subsection{Predicted Energy Performance}

The calibrated SUNREL model of the as-built building was used to predict the annual energy performance with different concrete thermal properties and HVAC control strategies. The as-built building is referred to as the test case for comparison with a base-case building. A building that meets the ASHRAE/IESNA Standard 90.1-1999 [7] for energy-efficient buildings was evaluated to create the basecase building. Internal loads were included to model a typical office building. Simulations were performed in Lansing, Michigan, and Phoenix, Arizona, to test the building in heating and cooling climates. Typical Meteorological Year 2 [5] weather data were used for the simulations.

Because SUNREL does not model HVAC system performance, the numbers presented are the heating and cooling energies required by the building to maintain the thermostat set points. System inefficiencies and fan energy required for air distribution cause the actual energy purchased to be higher. The economizer on the main floor is modeled as a fan-driven ventilation of outside air based on the air change rates measured with the tracer gas tests (Figure 16). The economizer energy is vented to the outside. If there were no economizer, this load would have to be met by the mechanical cooling equipment.

The insulation levels and window parameters for the base-case building and the test-case building are shown in Table 5. The base-case building is identical to the test-case building except that standard concrete is used, the insulation levels are lower, the windows have a lower solar heat gain coefficient, and no overhangs are included. The base-case building does not include daylighting, and the other buildings 
have lower internal heat gains to simulate the effects of partial daylighting. Because the building is small and there are few lights, the effect of the daylighting on the internal gains is also small.

Table 5. Comparison of the Test Case and Base-Case Buildings

\begin{tabular}{|c|c|c|c|}
\hline Component & $\begin{array}{c}\text { Test-Case } \\
\text { Lansing }\end{array}$ & $\begin{array}{l}\text { Test-Case } \\
\text { Phoenix }\end{array}$ & Base Case \\
\hline Insulation value $\left(\mathrm{hr}^{\prime} \cdot \mathrm{ft}^{2} \cdot{ }^{\circ} \mathrm{F} / \mathrm{Btu}\right)$ & & & \\
\hline Walls, above grade & $\mathrm{R}-25$ & $\mathrm{R}-25$ & $\mathrm{R}-8$ \\
\hline Walls, below grade & $\mathrm{R}-15$ & R-5 (top 4ft) & none \\
\hline Roof & $\mathrm{R}-35$ & $\mathrm{R}-35$ & $\mathrm{R}-15$ \\
\hline Basement floor & $\mathrm{R}-10$ & none & none \\
\hline Window U-value $\left(\mathrm{Btu} / \mathrm{hr} \cdot \mathrm{ft}^{2} \cdot{ }^{\circ} \mathrm{F}\right)$ & 0.46 & 0.46 & 0.57 \\
\hline Window SHGC & 0.65 & 0.39 & 0.39 \\
\hline Overhang length (ft) & 5 & 5 & 0 \\
\hline Daylighting & yes & yes & no \\
\hline
\end{tabular}

The annual heating and cooling loads for Lansing are shown in Figure 24. The test-case building with plastic aggregate concrete reduces heating energy requirements by more than $54 \%$ and overall HVAC energy by $40 \%$ compared to the base-case building with standard concrete. The cooling energy in the testcase building increased because the base-case building is partially cooled by direct contact with the ground. The test-case building is energy efficient because it is well insulated, especially on the underground surfaces. By contrast, there is no below grade insulation in the base-case building.

The effects of the concrete aggregates on the heating and cooling loads are also shown in Figure 24. The first two bars compare the base-case building with standard concrete and mixed plastic aggregate concrete. The second building uses $20 \%$ less energy for heating than the same building with standard concrete. The last four bars show the energy use of the test-case building with different concrete types and with a wood frame lightweight construction. Compared to the building with standard concrete, the testcase building with plastic concrete uses $8 \%$ less energy for heating and $6 \%$ less energy overall. The building with wood aggregate concrete uses $16 \%$ less heating energy and $11 \%$ less energy overall compared with the building with standard concrete. The lightweight building has the same insulation levels but does not have concrete walls or a concrete interior floor. The test-case building uses $16 \%$ less energy for heating and cooling than the lightweight building.

The energy savings from using different concrete come mostly from the difference in the concrete's thermal conductivity. The base-case building has lower insulation levels, so the effects of changing the concrete are larger than in the highly insulated test-case building. Adding more insulation would produce similar effects as lowering the thermal conductivity of the concrete. An economic analysis including the life cycle costs of the recycled-content concrete versus the cost of added insulation would have to be conducted to fully assess its potential. This technology would probably have the highest impact on underground walls and slab-on-grade floors that are more difficult to insulate.

The annual heating and cooling loads for the test-case building in Phoenix are shown in Figure 25. The building with the plastic concrete reduced the overall energy load by $4 \%$ compared to the building with standard concrete and more than 13\% compared to the lightweight building. The savings with the recycled-content concrete are smaller in the cooling climate than in the heating climate. This is expected because the average temperature difference across the building envelope is higher in Lansing than in Phoenix and leads to higher energy losses to the ambient conditions. 


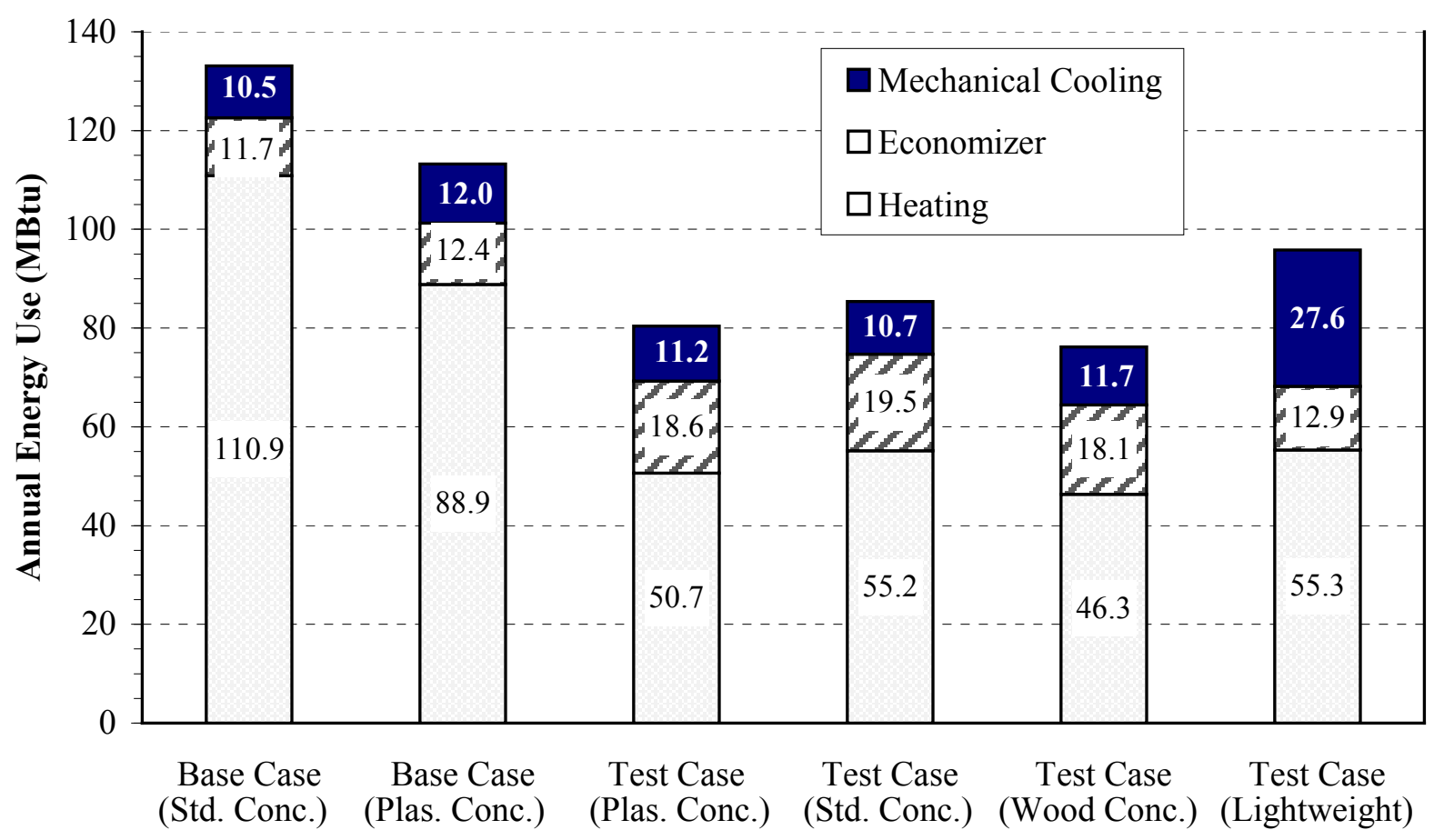

Figure 24. Annual heating and cooling energy use for Lansing, Michigan

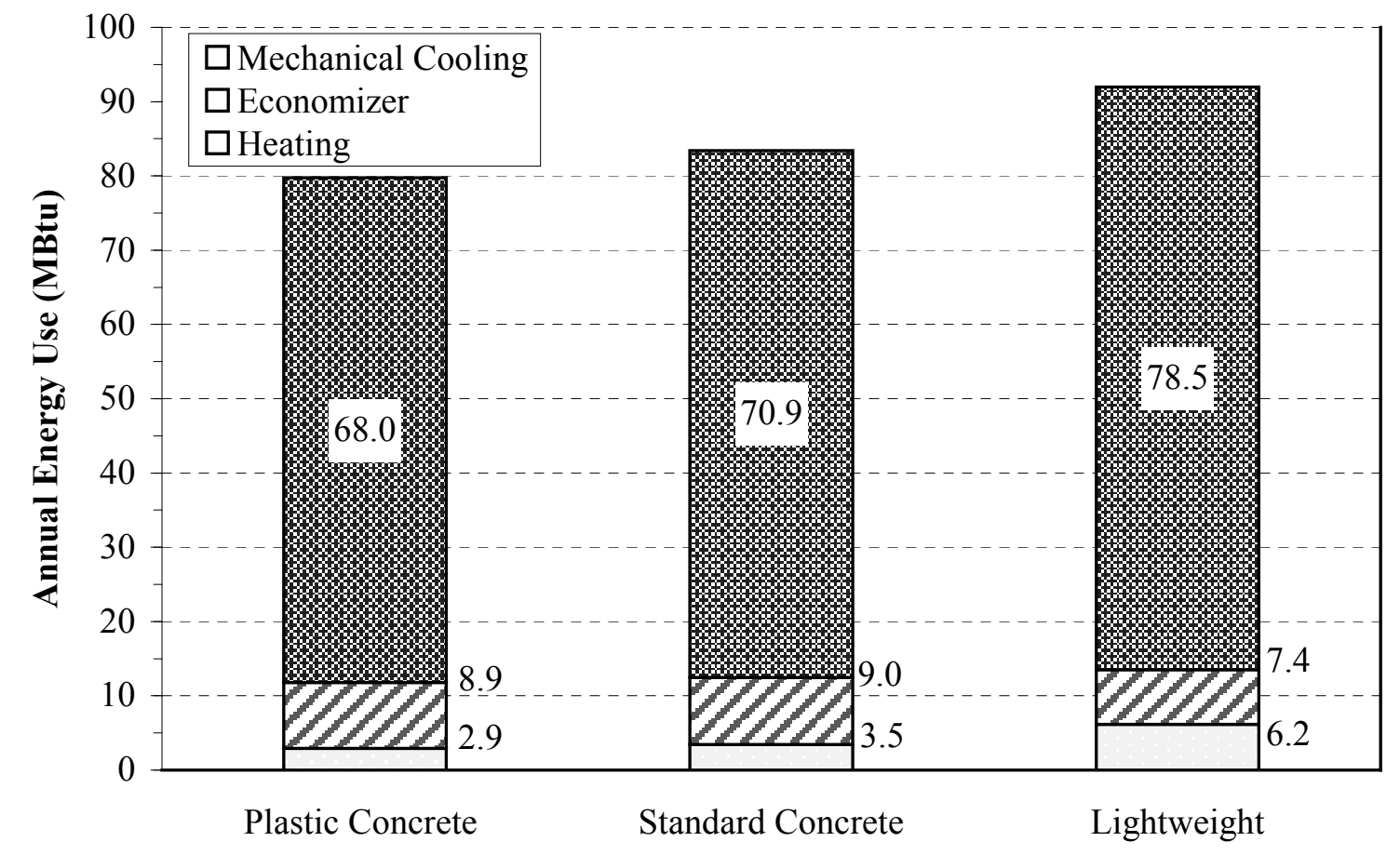

Figure 25. Annual heating and cooling energy for the test-case building in Phoenix, Arizona

Another advantage of thermally massive buildings is that they can smooth out temperature swings. To exhibit this behavior, the as-built building models with plastic-concrete and lightweight constructions 
were run with no heating, venting, or cooling with the Lansing weather file. The predicted minimum and maximum temperatures of the main floor for both cases along with the ambient extremes are shown in Figure 26. The maximum temperature in the lightweight building reaches $128^{\circ} \mathrm{F}\left(53^{\circ} \mathrm{C}\right)$ in October; in the massive building, it was only $94^{\circ} \mathrm{F}\left(34^{\circ} \mathrm{C}\right)$ in September. The minimum temperature in the massive building was $23^{\circ} \mathrm{F}\left(-5^{\circ} \mathrm{C}\right)$ and in the lightweight building, it was $6^{\circ} \mathrm{F}\left(-14^{\circ} \mathrm{C}\right)$. Another set of simulations was conducted to see how much heat would be required to prevent freezing in the buildings. With a heating set point of $35^{\circ} \mathrm{F}$, the massive building required only $1.7 \mathrm{MBtu}$ of heat, and the lightweight building required 5.7 MBtu of heat. Another impressive comparison of the two constructions is to look at the maximum temperature swing in one day over the year. The maximum daily temperature swing in the massive building was $8^{\circ} \mathrm{F}\left(-13^{\circ} \mathrm{C}\right)$, while in the lightweight building it was almost $40^{\circ} \mathrm{F}\left(4^{\circ} \mathrm{C}\right)$. This was a simple demonstration, but it shows that thermally massive construction can improve comfort by avoiding large temperature swings, and it can help with freeze protection if properly insulated.

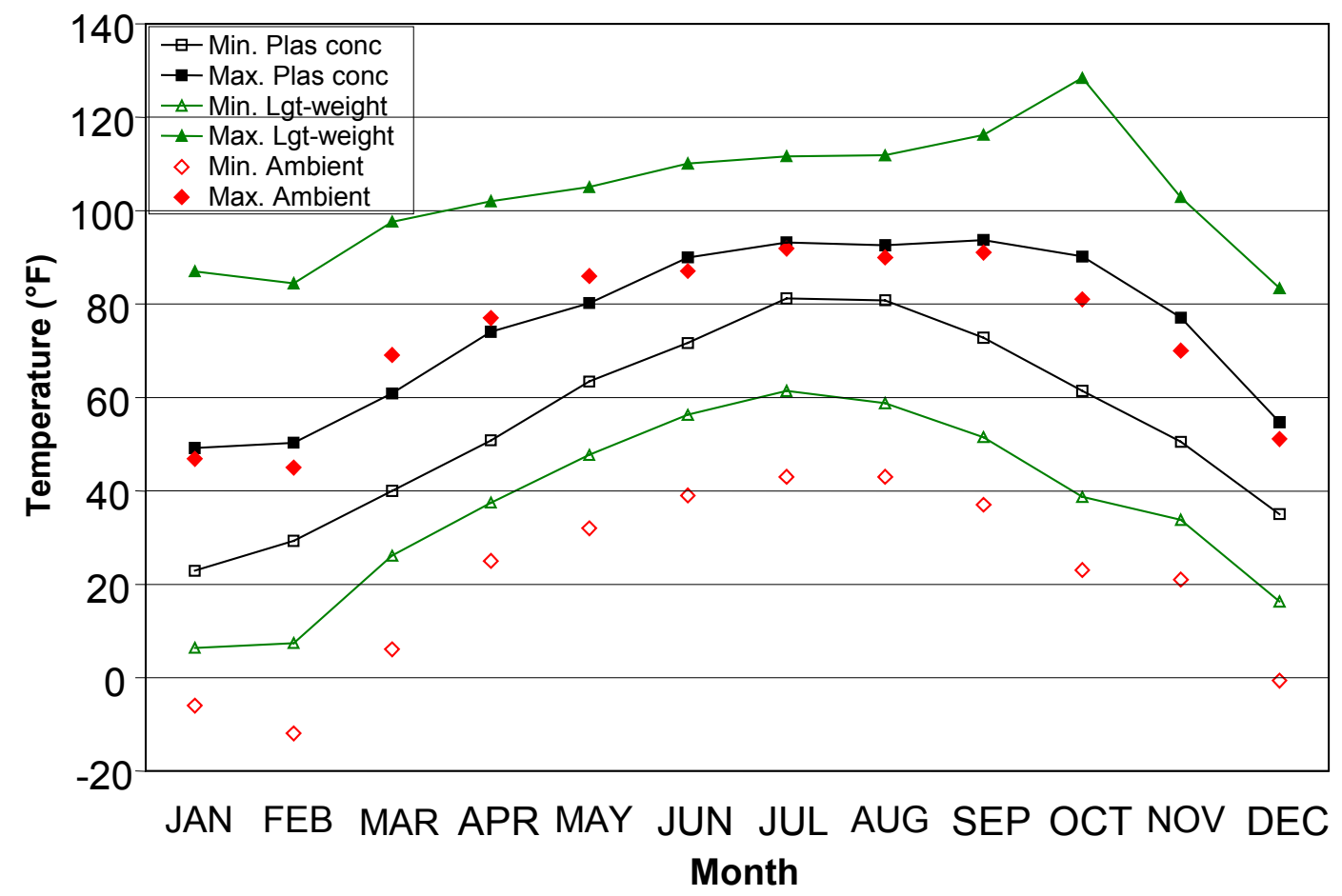

Figure 26. Free-floating minimum and maximum temperatures on the main floor in Lansing

\subsection{Optimal Control Strategies}

The optimal HVAC control strategies for high thermal mass buildings are not as straightforward as for lightweight buildings because of the effect of the stored energy in the building. The energy saving associated with the use of a night setback of the heating set point in high mass buildings is less than in lightweight buildings [8]. A simple investigation of this issue was conducted using the calibrated building model. Simulations were conducted with the base-case and test-case buildings with different constructions and different heating control strategies. The control strategies were a constant heating set point of $70^{\circ} \mathrm{F}\left(21^{\circ} \mathrm{C}\right)$, a night setback of $60^{\circ} \mathrm{F}\left(16^{\circ} \mathrm{C}\right)$ from 6:00 p.m. to 7:00 a.m., and a night setback of $55^{\circ} \mathrm{F}\left(13^{\circ} \mathrm{C}\right)$ from 6:00 p.m. to 7:00 a.m. High mass construction was compared with the lightweight construction of wood frame walls. The percent energy savings with the night temperature setback over a constant set point are shown in Table 6, along with the ratio of heat capacity and loss coefficient (UAvalue). The base-case building with lightweight construction had a larger saving than the high mass 
building, agreeing with Burch et al. [8]. The reason for the low savings in the test-case building with standard concrete is unknown. When the thermostat was reduced to $55^{\circ} \mathrm{F}\left(13^{\circ} \mathrm{C}\right)$ at night instead of $60^{\circ} \mathrm{F}$ $\left(16^{\circ} \mathrm{C}\right)$, the savings were reduced. There does not seem to be any correlation between the energy savings and the ratio of heat capacity and loss coefficient.

The thermal mass must be insulated from ambient conditions and in direct contact with interior space conditions for the mass to store excess heat when the building is hot and release it later when it is cooler. This "breathing" of heat produces a time lag in the response of the building. The effect of the time lag on the control strategy was not investigated in this report but needs to be considered when setting the thermostat. The morning temperature setup should be started earlier to allow the massive building to warm up before the occupants arrive; it should then be set back earlier in the evening.

Setting the cooling set point higher at night can also produce some savings; however, the heat gain in office buildings is very low at night, and the savings are much smaller than for a heating setback. One strategy that can help cool buildings is to use natural ventilation at night when the ambient temperature is lower than the building temperature. If natural ventilation cannot be used or does not provide enough cooling, ventilation fans can be used. Nighttime cooling is most effective with high mass buildings, which can maintain a cool interior temperature longer during the day than lightweight buildings.

Table 6. Energy Savings with a Night Setback from $70^{\circ} \mathrm{F}$ to $60^{\circ} \mathrm{F}$ Compared to no Setback

\begin{tabular}{|l|c|c|}
\hline \multicolumn{1}{|c|}{ Case Description } & $\begin{array}{c}\text { Heat Cap./UA } \\
\text { (h) }\end{array}$ & $\begin{array}{c}\text { \% Reduction in } \\
\text { Heating Energy }\end{array}$ \\
\hline \hline Base case with plastic concrete & 480 & 21.7 \\
\hline Base case with standard concrete & 333 & 21.1 \\
\hline Base case with wood frame walls & 276 & 24.6 \\
\hline Test case with plastic concrete & 737 & 17.8 \\
\hline Test case with standard concrete & 586 & 6.8 \\
\hline Test case, plastic concrete, $55^{\circ} \mathrm{F}$-setback & 737 & 16.2 \\
\hline
\end{tabular}

\section{Daylighting}

The savings from daylighting in these office buildings are smaller than from most office buildings, because they are small with relatively few electric lights to offset with natural light; however, daylighting can help reduce energy demand. There are no daylighting controls in the north building, so savings will depend on the users to control the electric lights with the changing natural lighting conditions.

\subsection{Daylight Monitoring}

Daylighting measurements were taken on the main floor of the south building from July 22-25 and from December 1-3 with the electric lights off. Sixteen photometers were placed in a grid arrangement covering the main floor at a height of 30 in $(76 \mathrm{~cm})$ above the floor, and the readings were recorded every 15 minutes with a data logger. In addition, hand-held measurements were taken every two hours during the day in 48 locations in a 5 - $\mathrm{ft}(1.5 \mathrm{~m})$ grid pattern over the floor.

Contour plots of the data from two of the hand-held measurement sets are shown in Figures 27 and 28. The measurements are reported in lux (lumens per square meter). Standard illumination levels on the working surface for an office building are 300-500 lux (30-50 fc) [9]. The data in Figure 27 were measured at 4:00 p.m. on December 1,2000, which was a cloudy day with all diffuse solar radiation. This shows a good distribution of diffuse light with no contrast problems. Electric lights may be needed in the left side of the figure. The data in Figure 28 were recorded at 11:00 a.m. on December 2, 2000, which was a clear day with high beam radiation. Now there is direct beam radiation in the space with light levels 
exceeding 30,000 lux. Illuminance at this level produces glare problems and makes it difficult to work facing a window or at a video display terminal facing any direction. The light levels in the far west portion of the building drop off to 1000-3000 lux, which would provide contrast problems with the highly lit east side of the building.

The high beam radiation and the contrast problems are due to the large window area in a small space with no method of controlling the solar gain. Blinds must be used to block or redirect the light entering the space. Ideally, two sets of blinds would be installed: one on the top section of windows and one below the mullion at the top of the door. This would allow the light through the top section of windows to be redirected to the ceiling for diffuse lighting and would allow control of the beam radiation on the working spaces.

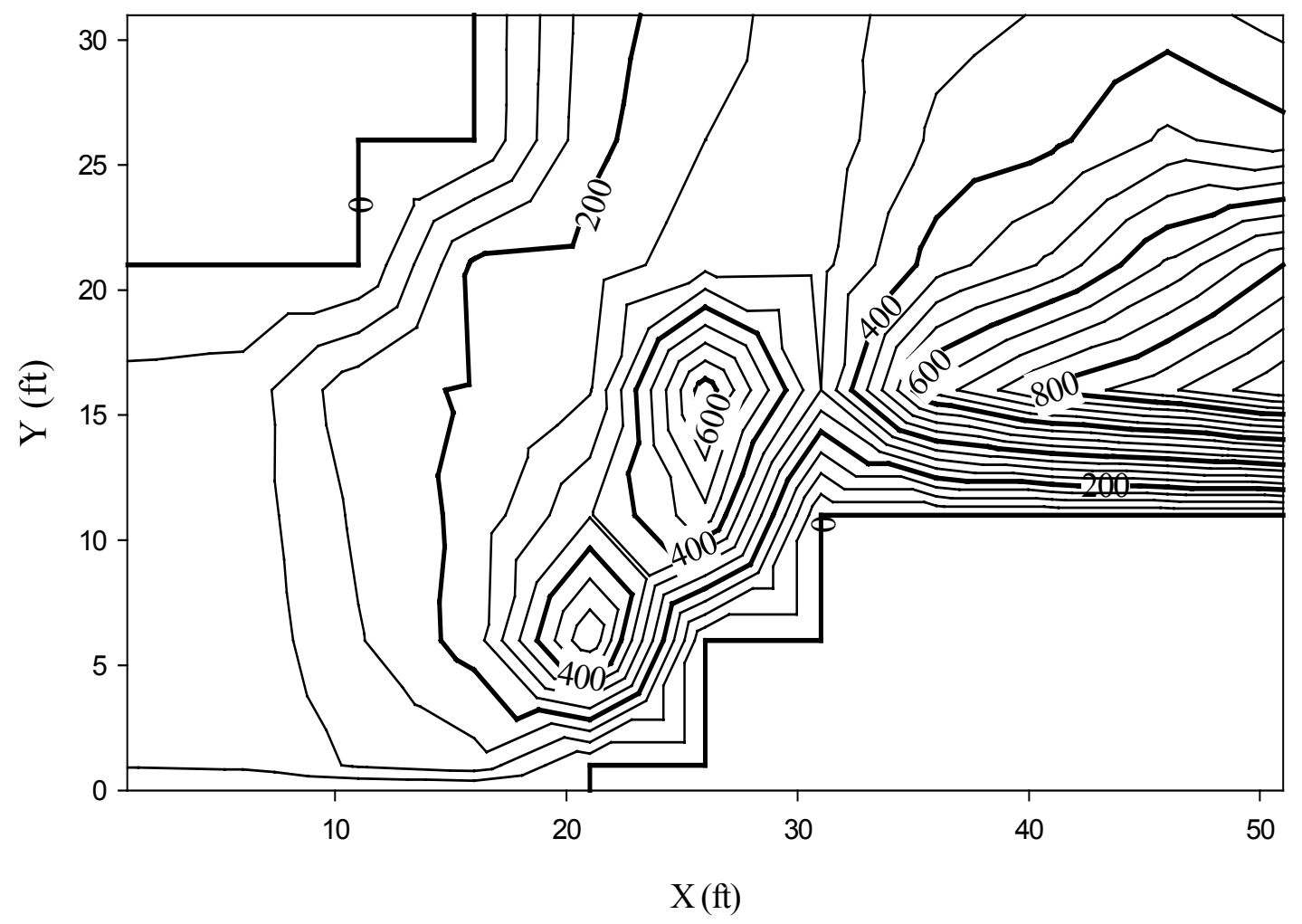

Figure 27. Contours of the illuminance (lux) at 4:00 p.m. on December 1, 2000, with cloudy skies 


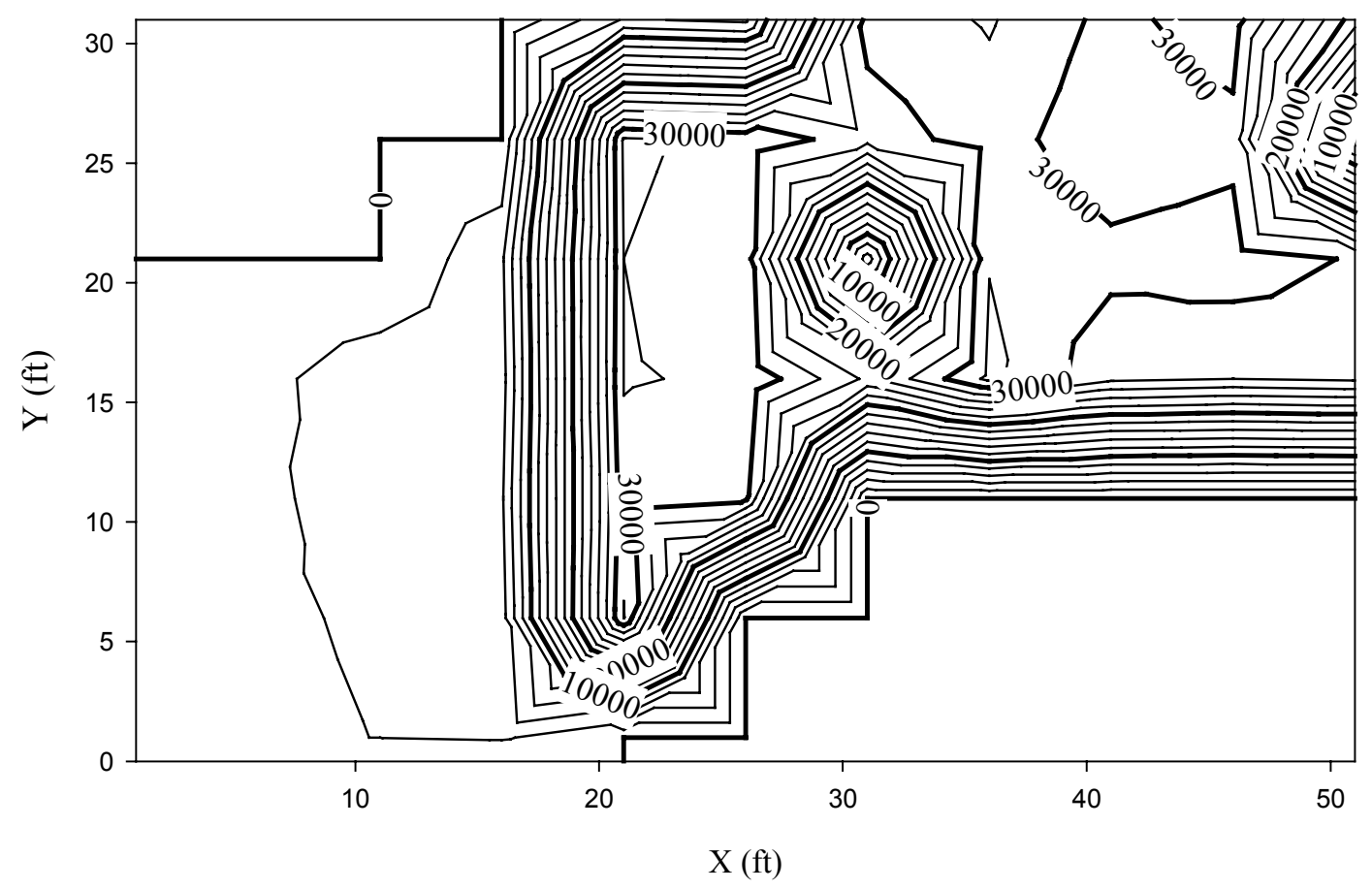

Figure 28. Contours of the illuminance (lux) at 11:00 a.m. on December 2, 2000, with clear skies

\subsection{Daylight Modeling}

The electrical energy savings associated with daylighting were estimated using DOE2.1E and are shown in Figure 29. The electrical energy used for lighting was reduced by more than half and the cooling energy by almost $20 \%$. The total annual electrical energy was reduced by almost $28 \%$ from $22.4 \mathrm{MW} / \mathrm{h}$ to 16.2 MW/h. Reducing the light level also reduces the heat added to the space; therefore, the heating load increases in the winter. For this building, the use of natural gas increased by $13 \%$ when daylighting was included to offset the reduced heat gain from the lights. The overall effect of daylighting reduced the total annual energy cost by $18 \%$ and the total source energy use by $20 \%$. Note that there is no electric demand charge for small commercial buildings in Lansing, which would improve the cost savings. 

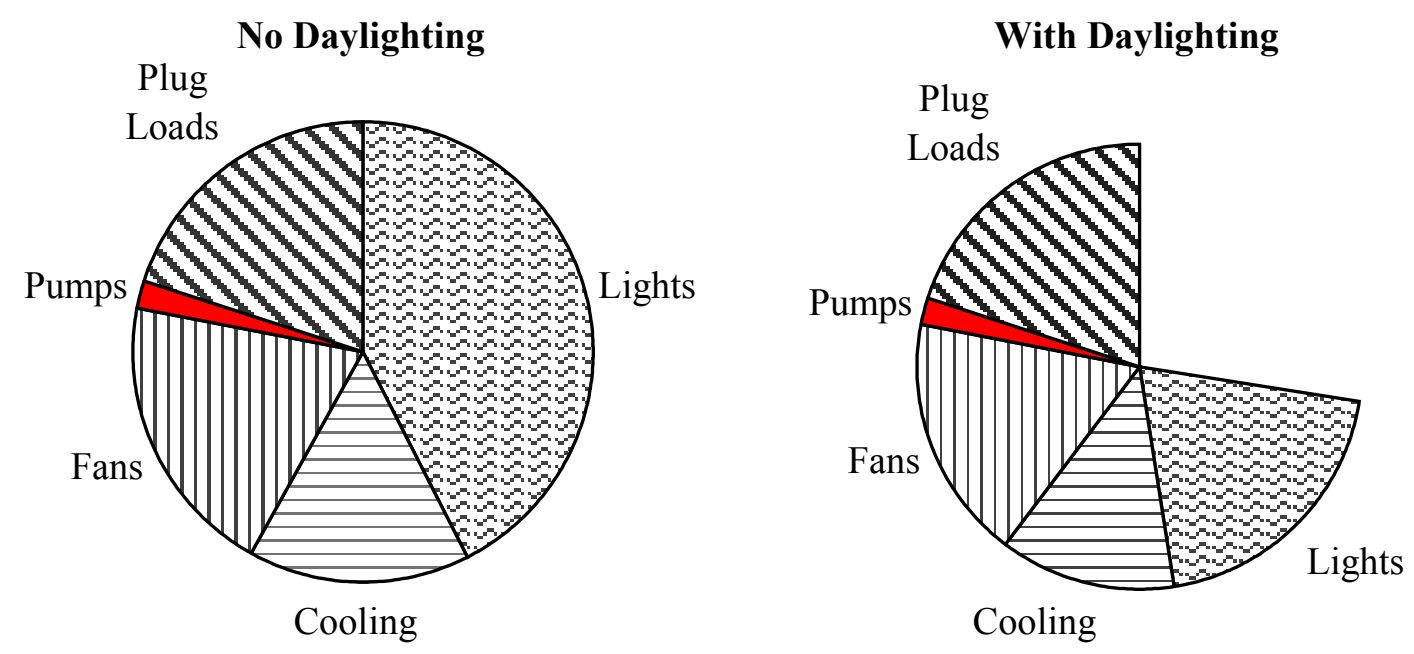

Figure 29. Electrical loads with no daylighting and with daylighting

\section{Conclusions}

The use of recycled-content concrete produced energy savings in the small office building analyzed in this report compared to the same building with standard concrete. A highly insulated building with the SSH-Plastic concrete was predicted to use $8 \%$ less energy for the annual heating load than the same building with standard concrete in the heating climate of Lansing, Michigan. The same buildings with windows with a lower solar heat gain coefficient were simulated in the cooling climate of Phoenix, Arizona, and showed overall heating and cooling savings of $4 \%$ when the SSH-Plastic concrete was used. The savings in the cold climate are even more impressive when the SSH-Plastic concrete is used in a building with lower insulation levels. A similar building with insulation levels compliant with ASHRAE Standard 90.1-1999 and SSH-Plastic concrete would use 20\% less energy for heating than a building with standard concrete. The savings are predominantly from the lower thermal conductivity of the concrete with the plastic aggregate.

The use of recycled materials in the concrete is advantageous from an energy point of view. This is especially true for buildings that have insulation levels at or below the energy code levels. This type of concrete may be especially useful for underground walls and floors, which are more difficult to insulate. This can be easily shown by looking at the R-value of an 8 -in wall with standard concrete (R-1.1 $\mathrm{ft}^{2} \cdot{ }^{\circ} \mathrm{F} \cdot \mathrm{h} / \mathrm{Btu}$ ) versus a wall made with the plastic concrete used in this report (R-4.2 $\left.\mathrm{ft}^{2} \cdot{ }^{\circ} \mathrm{F} \cdot \mathrm{h} / \mathrm{Btu}\right)$. The higher R-value would not only reduce the heat loss through the walls, but it may also reduce condensation on the interior surface. The effect of the increased thermal capacitance of the recycled-content concrete shows a small advantage over the use of standard concrete.

Buildings with a high amount of thermal mass are more energy efficient and reduce temperature swings compared to buildings with lightweight construction. Compared to a lightweight building, the as-built building was shown to require 16\% less heating and cooling energy in Lansing and 13\% less energy if it was constructed in Phoenix.

Short- and long-term monitoring of the energy use in the two office buildings was used to evaluate the performance of the buildings and calibrate a computer model of the energy performance. The calibrated model was shown to be within $2 \%$ of the measured heating load on the south building. Using the computer model, the south building used $40 \%$ less energy for heating and cooling than a similar building that meets the minimum energy performance of ASHRAE Standard 90.1-1999. The north building has more glass area and is partially shaded by the south building, so its energy performance is lower. 
Simulations of the north building predict that it will use about the same amount of energy for cooling but $13 \%$ more for heating than the south building.

Both buildings are energy efficient, but the large window areas in a small space may cause comfort problems. The inside glass surface will be cold on winter days when the sun does not shine on the windows. This will reduce the comfort of the occupants by lowering the mean radiant temperature and generate a draft of cold air flowing down the surface of the glass. In the summer, direct gain from the windows may overheat occupants sitting in the sunlight. Computer models did not show overheating of the whole building by direct solar gain to be a problem, primarily because of the large thermal mass. The windows also transmit a large amount of natural light into the space, which may cause contrast and glare problems. Daylighting measurements showed extreme light levels for clear sky conditions. The overheating and lighting problems can be somewhat controlled with window blinds. Two sets of blinds should be installed to better control the daylighting. The mullion that divides the windows provides a break point for the blinds. The bottom blind could be adjusted to control the direct glare on the work surfaces and the view to the outside, and the top blind could be adjusted to redirect the sunlight to bounce off the ceiling to produce a diffuse reflection into the space.

An important part of energy conservation in buildings is the control of the energy systems. The control in these buildings is very simple using programmable thermostats. Placing the heating set point back $10^{\circ} \mathrm{F}$ for 12 hours at night saves $18 \%$ on the heating energy for the as-built building. Setting the temperature back $15^{\circ} \mathrm{F}$ at night saved only $16 \%$, so too much setback can reduce the energy savings in massive buildings. Control of the lights is also very important, as lights are the largest electrical load on the building (see Figure 29). The south building has daylighting controls on the main floor, but the north building has no daylighting controls; therefore, the savings is dependent on whether the occupants turn off the electric lights when there is adequate daylighting.

\section{References}

[1] DOE2.1E whole-building energy simulation program from the U.S. Department of Energy, http://simulationresearch.lbl.gov/, last accessed on February 28, 2003.

[2] SUNREL whole-building energy simulation program from the National Renewable Energy Laboratory, http://www.nrel.gov, last accessed on February 28, 2003.

[3] Soroushian, P. Personal communication, Michigan State University, 1998.

[4] ASTM E 779-87 Standard Test Method for Determining Air Leakage Rate by Fan Pressurization. American Society for Testing and Materials, Philadelphia, PA, 1992.

[5] Typical Meteorological Year 2 Weather Data available from http://rredc.nrel.gov/solar/old_data/nsrdb/tmy2/, last accessed on February 28, 2003.

[6] ASHRAE Standard 62-1999, Ventilation for Acceptable Indoor Air Quality. American Society of Heating, Refrigerating, and Air Conditioning Engineers, Atlanta, GA, 1999.

[7] ASHRAE/IESNA Standard 90.1-1999, Energy Standard for Buildings Except Low-Rise Residential Buildings. American Society of Heating, Refrigerating, and Air Conditioning Engineers, Atlanta, GA, 1999.

[8] Burch, D. M.; Johns, W.L.; Jacobsen, T.; Walton, G.N.; Reeve, C.P. "The Effect of Thermal Mass on Night Temperature Setback Savings.” ASHRAE Transactions, Vol. 90 (2A), 1984; pp. 184-206.

[9] IESNA Lighting Handbook ninth ed.2000. Illuminating Engineering Society of North America, New York. 


\section{REPORT DOCUMENTATION PAGE}

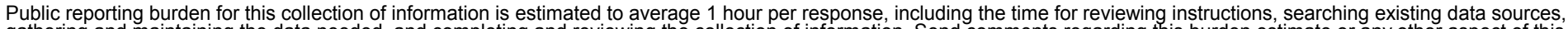

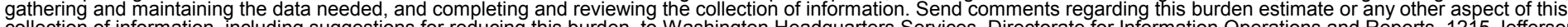
Davis Highway, Suite 1204, Arlington, VA 22202-4302, and to the Office of Management and Budget, Paperwork Reduction Project (0704-0188), Washington, DC 20503.
1. AGENCY USE ONLY (Leave blank)
2. REPORT DATE
March 2003
3. REPORT TYPE AND DATES COVERED
Technical Report

4. TITLE AND SUBTITLE

Final Project Report for DPD, Inc. Office Building in Lansing, Michigan
5. FUNDING NUMBERS

BEC2.4002

6. AUTHOR(S)

M. Deru and M. Sherman

7. PERFORMING ORGANIZATION NAME(S) AND ADDRESS(ES)

National Renewable Energy Laboratory

1617 Cole Blvd.

Golden, CO 80401-3393

9. SPONSORING/MONITORING AGENCY NAME(S) AND ADDRESS(ES)
8. PERFORMING ORGANIZATION

REPORT NUMBER

NREL/TP-550-33108

10. SPONSORING/MONITORING AGENCY REPORT NUMBER

11. SUPPLEMENTARY NOTES

12a. DISTRIBUTION/AVAILABILITY STATEMENT

National Technical Information Service

12b. DISTRIBUTION CODE

U.S. Department of Commerce

5285 Port Royal Road

Springfield, VA 22161

13. ABSTRACT (Maximum 200 words)

The National Renewable Energy Laboratory participated with DPD, Inc., in the thermal analysis of buildings constructed using concrete with recycled materials in the aggregate. This project was part of a Phase II Small Business Innovative Research grant to determine how the thermal properties of concrete can be "tuned" for use in passive solar buildings. DPD Inc. and Michigan State University developed techniques to alter the thermal properties of concrete by introducing recycled materials into the aggregate. Two office/retail buildings were built in Lansing, Michigan for this research. The objective of NREL's involvement was to evaluate the effects of concrete thermal properties on the building performance through energy simulations and monitoring. This report presents a summary of work accomplished on this project, including a predesign analysis of the concrete properties and building designs as well as energy performance analysis after construction. The test results were used to calibrate computer models that were later used to predict long-term performance of the buildings.

14. SUBJECT TERMS

DPD; concrete; recycled materials; Michigan; thermal properties; concrete properties

15. NUMBER OF PAGES

16. PRICE CODE

17. SECURITY CLASSIFICATION OF REPORT Unclassified
18. SECURITY CLASSIFICATION OF THIS PAGE Unclassified
19. SECURITY CLASSIFICATION OF ABSTRACT Unclassified
20. LIMITATION OF ABSTRACT

UL 